Asy Syar'iyyah: Jurnal Ilmu Syari'ah dan Perbankan Islam - ISSN 2089-7227 (p)

2598-8522 (e)

Vol. 6, No. 2, Desember 2021, pp. 161-201

\title{
ANALISIS KRITIS EKSISTENSI BUNGA BANK SEBAGAI RIBA KEUANGAN KONTEMPORER
}

\author{
Muhammad Syarif Hidayatullah \\ Program Doktor Ilmu Syariah Pascasarjana UIN Antasari Banjarmasin \\ syarif.muhammad849@gmail.com
}

\begin{abstract}
This study is based on the background that the existence of bank interest in a modern economy is a manifestation of usury in financial institutions. This paper aims to critically analyze the practice of interest in money and the existence of bank interest as contemporary financial riba from various perspectives including a review of Islamic law. This paper also seeks to respond to opinions that serve as the basis for efforts to legalize bank interest. Bank interest is a contemporary manifestation of usury in modern business operations and one that makes it the center of profit in its business is conventional banks. By using the qiyas method in istinbat al-hukm bank interest, the practice of usury as ashl and bank interest as far ', both of which are put together in the same' illat, namely the addition without any compensation. Therefore, the prohibition of usury applies to the law of bank interest. This practice of bank interest also violates the Islamic legal maxim alghurmu bi al-ghunmi and al-kharaj bi adh-dhamân and is a representation of the principle of time value of money (capitalist economic system). Provisions on the prohibition of bank interest have also been issued by various scholars forums both nationally and internationally.
\end{abstract}

Keywords: Interest, Usury; Conventional Bank; Contemporary Finance

\section{Abstrak}

Kajian ini dilatarbelakangi bahwa eksistensi bunga bank dalam perekonomian modern merupakan perwujudan riba di lembaga keuangan. Tulisan ini bertujuan untuk menelaah secara kritis praktik pembungaan uang dan 
eksistensi bunga bank sebagai riba keuangan kontemporer dari berbagai perspektif termasuk tinjauan hukum Islam. Selain itu juga tulisan ini berupaya menanggapi pendapat-pendapat yang dijadikan landasan dalam upaya melegalkan bunga bank. Bunga bank adalah perwujudan riba kontemporer dalam operasional bisnis modern dan salah satu yang menjadikannya pusat keuntungan dalam bisnisnya adalah bank konvensional. Dengan menggunakan metode qiyas dalam istinbat al-hukm bunga bank, maka praktik riba sebagai ashl dan bunga bank sebagai far', keduanya disatukan dalam 'illat yang sama yaitu adanya tambahan tanpa disertai imbalan. Karena itu keharaman riba berlaku pada hukum bunga bank. Praktik bunga bank inipun menyalahi kaidah al-ghurmu bi al-ghunmi dan al-kharaj bi adhdhamân serta menjadi representasi prinsip time value of money (sistem ekonomi kapitalis). Ketetapan tentang keharaman bunga bank juga telah banyak dikeluarkan oleh berbagai forum ulama baik yang bertaraf nasional maupun internasional

Keywords: Bunga; Riba; Bank Konvensional; Keuangan Kontemporer

\section{A. Pendahuluan}

Riba merupakan salah satu transaksi yang diharamkan dalam hukum Islam. Praktik riba benar-benar merupakan perbuatan zalim dan sangat merugikan. Oleh karena itu praktik riba termasuk salah satu dosa besar. ${ }^{1}$ Bahkan menurut Abû Zahrah, bahwa praktik riba selain diharamkan dalam agama Islam juga diharamkan dalam agama Yahudi dan Nasrani serta para ahli filsafatpun juga mengharamkannya. ${ }^{2}$ Dalam arus perkembangan zaman, riba tidak lagi dilakukan secara individual atau personal, melainkan sudah dipraktikkan secara institusional melalui lembaga keuangan yang salah satunya adalah bank. Praktik pembungaan uang menjadi jantung usaha dalam operasional bank baik itu dalam produk penghimpunan dana seperti tabungan, giro dan deposito maupun pembiayaan baik itu konsumtif maupun produktif.

Bunga bank adalah bentuk riba keuangan kontemporer yang sudah

\footnotetext{
${ }^{1}$ Rafîq Yûnus al Mishrî, al-Jâmi’ fî Ushûl ar-Ribâ (Damaskus: Dâr al-Qalam, 2001), 16.

${ }^{2}$ Muhammad Abû Zahrah, Buhûts fî̀ ar-Ribâ (Kairo: Dâr al-Fikr al'Arabî), 3-7.
} 
bergeser praktiknya dari individual kepada institusional serta peralihan dari tanpa struktur menjadi terstruktur berdasarkan manjemen perusahaan yang menggerakkan roda bisnisnya. Bisnis ini berjalan melalui pembungaan uang yang operasionalnya dikerjakan para karyawan dengan pengorganisasian yang tersusun sesuai kerja. Walaupun Majelis Ulama Indonesia (MUI) telah mengeluarkan fatwa haramnya bunga bank karena termasuk dalam riba nasi'ah dan keharamannya pula banyak difatwakan oleh lembaga fatwa bertaraf nasional maupun internasional, tapi tetap saja banyak pihak yang berusaha melegalkan praktik riba ini dengan berbagai alasan bahwa bunga bank yang menjadi penarikan keuntungan di bank konvensional bukanlah riba sehingga boleh diterima.

Produk-produk ekonomi syariah di Indonesia sendiri telah mengalami perkembangan dari masa ke masa. Hal itu ditunjukkan dengan hadirnya banyak lembaga keuangan syariah dan juga bisnis industri halal yang keberadaannya tidak lain untuk mendukung kemajuan ekonomi syariah yang menjadi kebutuhan dalam bertransaksi di masa sekarang. ${ }^{3}$ Hadirnya bank syariah sebagai wujud pengaplikasian hukum Islam tentang muamalah dalam lembaga keuangan modern merupakan hasil jerih payah dan perjuangan para ulama, cendekiawan dan ekonom muslim untuk dapat menegakkan prinsip syariah dalam kegiatan ekonomi perbankan. Ini pula adalah bentuk upaya mengaplikasian kandungan Q.S an-Nisâ (4): 29 agar tidak memakan harta sesama dengan cara yang bathil dan salah satu transaksi yang bathil itu adalah praktik pembungaan uang yang merupakan transaksi ribawi yang menjadi roda bisnis bank konvensional. ${ }^{-}$Selain itu juga dilatarbelakangi keinginan masyarakat agar dapat bertransaksi perbankan dengan tetap berpegang pada prinsip-prinsip syariah dalam akadnya dan terhindar

\footnotetext{
3 Fitriani Fitriani and Indra Marzuki, 'Analisis penerapan aspek syariah pada digitalisasi Bisnis pariwisata halal':, Al-Mizan: Jurnal Hukum dan Ekonomi Islam, vol. 4, no. 2 (2020), 82.

4 Hendra Cipta, 'Jual Beli yang Diridhoi dalam Perspektif Surat An-Nisa' (4) Ayat 29', ASY SYAR'IYYAH: JURNAL ILMU SYARI'AH DAN PERBANKAN ISLAM, vol. 3, no. 2 (2018), 60.
} 
daripada riba dan transaksi terlarang lainnya. ${ }^{5}$

Bank syariah secara konseptual berbeda dengan bank konvensional yang melakukan pembungaan uang, karena secara operasional bank syariah berdasar pada prinsip syariah yang didalamnya sistem bunga adalah terlarang dan keuntungan yang diambil harus berdasarkan akad tijarah (komersial) yang diperbolehkan untuk diterapkan dalam muamalah seperti bagi hasil dalam akad musyarakah dan mudharabah, margin dalam akad jual beli murabahah, salam dan istishna' dan ujrah (upah/fee) dalam akad ijarah (jual beli manfaat jasa) serta pembiayaan hanya ditujukan pada sektor halal. ${ }^{6}$ Operasional Bank syariahpun dalam pengawasan Dewan Pengawas Syariah (DPS) dan pengaturan akad dan produk keuangan syariah berdasarkan fatwa Dewan Syariah Nasional Majelis Ulama Indonesia (DSN-MUI).

Kepatuhan syariah menjadi salah satu pilar penting eksistensi perbankan syariah dalam perkembangannya, karena dengan tegaknya pilar kepatuhan syariah ini, maka dari sinilah pembeda antara perbankan konvensional dengan perbankan syariah. ${ }^{7}$ Keberadaan DPS sebagai perpanjangan tangan DSN-MUI dalam melakukan pengawasan prinsip syariah diharapkan dapat mengawal kepatuhan syariah (shariah compliance) secara optimal pada perbankan syariah agar beroperasi sesuai dengan standar syariah yang digariskan, karena penerapan prinsip-prinsip syariah dalam perbankan syariah adalah suatu keharusan untuk diaplikasikan dan salah satunya terhindar dari praktik riba/pembungaan uang. ${ }^{8}$

\footnotetext{
5 Annas Syams Rizal Fahmi et al., 'Implementasi Fatwa Dsn-Mui No: 77/Dsn-Mui/V/2010 Terhadap Akad Murabahah Pada Produk Cicil Emas Di Bank Syariah Mandiri', Al-Mizan: Jurnal Hukum dan Ekonomi Islam, vol. 4, no. 2 (2020), 2.

${ }^{6}$ Rahmat Ilyas, 'Konsep Dasar Dalam Sistem Keuangan Syariah', ASY SYAR'IYYAH: JURNAL ILMU SYARI'AH DAN PERBANKAN ISLAM, vol. 2, no. 1 (2017), 131-4.

7 Wulpiah Wulpiah, 'Urgensi Penerapan Kepatuhan Syariah pada Perbankan Syariah (Telaah Konseptual-Analitis)', ASY SYAR'IYYAH: JURNAL ILMU SYARI'AH DAN PERBANKAN ISLAM, vol. 2, no. 1 (2017), 101.

${ }^{8}$ Marheni Marheni, 'Analisis Kepatuhan Prinsip-Prinsip Syariah Terhadap Kesehatan Finansial Dan Fraud pada Bank Umum Syariah', ASY SYAR'IYYAH: JURNAL ILMU SYARI'AH DAN PERBANKAN ISLAM, vol. 2, no. 1 (2017), 144; Sumar'in Sumar'in, 'Optimalisasi Peran Dewan Pengawas Syariah
} 
Tulisan ini bertujuan untuk menelaah secara kritis tentang praktik pembungaan uang dan eksistensi bunga bank konvensional sebagai riba keuangan kontemporer dalam berbagai pandangan termasuk tinjauan hukum Islam, serta berupaya menanggapi alasan-alasan yang dijadikan landasan mereka yang berupaya melegalkan bunga bank dalam kegiatan ekonomi dan bisnis.

\section{B. Eksistensi Bunga Bank Sebagai Riba Keuangan Kontemporer}

\section{Praktik Riba di Masa Lampau Sebelum Masehi}

Praktik riba sudah ada sejak zaman dahulu kala. Ditemukan buktibukti bahwa pada masa kejayaan Sumeria ( $+3000-1900$ SM) telah ada sistem kredit ribawi sistematik yang dipraktikkan dengan penerapan tingkat bunga $33 \%$ pertahun pada bahan makanan (gandum) dan sebesar $20 \%$ pertahun pada uang (perak). Ada satu regulasi di zaman babylonia ( yang diformulasikan Raja "Hamurabi" yang keberadaannya melegitimasi sekaligus memperkuat tingkat suku bunga yang diberlakukan pada masa Sumeria sebagai tingkat bunga yang legal menurut undang-undang Babyolonia. Ketetapan dalam regulasi tersebut berlangsung hingga hampir 1.200 tahun lamanya. Praktik riba ini berlangsung terus pada zaman Assyria (+732-655 SM), Yunani (500-100 SM), dan Romawi (500-90 SM). ${ }^{9}$

\section{Penyebarluasan Instrumen Bunga}

Disaat transaksi perbankan mulai dipraktikkan oleh bangsa Eropa, persoalan yang terjadi dilihat dari kacamata fikih Islam adalah praktik saat itu menjadikan bunga sebagai perangkat inti dalam operasional bisnis yang termasuk dalam kategori riba, karena itu hukumnya adalah haram. Transaksi pembungaan uang ini semakin mewabah dan meluas ketika di tahun 1545

(DPS) Dalam Menjaga Kepatuhan Syariah Pada Perbankan Syariah di Indonesia', ASY SYAR'IYYAH: JURNAL ILMU SYARI'AH DAN PERBANKAN ISLAM, vol. 2, no. 1 (2017), 196-220.

${ }^{9}$ M. Ma'ruf Abdullah, Hukum Perbankan dan Perkembangan Bank Syariah Di Indonesia (Banjarmasin: Antasari Press, 2006), 56. 
Raja Henry VIII membolehkan bunga (interest) walaupun tetap mengharamkan riba (usury) dengan syarat bunga yang diterapkan tidak boleh berlipat ganda (excessive). Dikala Raja Henry VIII wafat, maka posisinya digantikan oleh Raja Edward VI yang kemudian membatalkan kebolehan bunga uang, namun hal ini tidak berlangsung lama. Setelah Raja Edward VI wafat, maka Ratu Elizabeth I berkuasa dan ia kembali membolehkan praktek pembungaan uang. ${ }^{10}$ Dalam pendapat mereka terdapat perbedaan antara usury dan interest. Usury adalah tingkat bunga yang tinggi, dianggap tidak wajar dan memberatkan, sedangakan interest adalah tingkat bunga yang rendah, dianggap wajar dan ringan saja.

Disaat memasuki masa kebangkitan dari keterbelakangannya dan mengalami renaissance, penjelajahan dan penjajahan mulai dilakukan bangsa Eropa ke berbagai penjuru dunia yang mengakibatkan bangsa-bangsa Eropa mendominasi aktivitas ekonomi dan perekonomian dunia. Disaat yang sama, Peradaban umat Islam mengalami kemunduran dan negara-negara Muslim akhirnya satu persatu masuk dalam jajahan bangsa Eropa. Hal ini memberikan dampak negatif atau akibat buruk kepada umat Islam dengan institusi-institusi perekonomian umat Islam yang telah dibangun akhirnya runtuh dan mulai digantikan oleh institusi ekonomi bangsa Eropa. Kondisi ini terus berlangsung sampai sampai kini di zaman modern. Oleh sebab itu, institusi perbankan yang sekarang terbangun di mayoritas negara-negara Muslim adalah warisan dari bang Eropa yang notabennya menggunakan sistem berbasis bunga. ${ }^{11}$ Di negara kita sendiri Indonesia yang selama ratusan tahun dalam kekuasaan Belanda yang menjajah negeri ini, tidak lepas dari kehadiran institusi dengan sistem berbasis bunga karena Belanda mendirikan beberapa bank ${ }^{12}$ seperti De Javasche Bank, De Post Paar Bank dan lainnya

${ }^{10}$ Adiwarman A. Karim, Bank Islam: Analisis Fiqih dan Keuangan (Jakarta: RajaGrafindo Persada, 2008), 22.

${ }^{11}$ Ibid.

${ }^{12}$ Penyebarluasan instrument bunga dalam sistem inti lembaga keuangan. 
Muhammad Syarif Hidayatullah

serta bank-bank milik pribumi, Cina, Jepang dan Eropa seperti Bank Nasional Indonesia, Batavia Bank dan lainnya. ${ }^{13}$

\section{Konsep Riba Dikalangan Agama Samawi}

Dalam kosa kata Bahasa Inggris, riba biasanya diterjemahkan sebagai usury, sedangkan bunga diterjemahkan sebagai interest. Dilarangnya riba oleh agama-agama Samawi, tidak ada yang membantah, setidaknya itulah yang ditulis dalam Taurat dan Injil. Lihatlah dalam Perjanjian Lama (Levictus [Imamat] 25: 36-37, Deuteronomy [Ulangan] 23: 19, Exodus [Keluaran] 22: 25), juga dalam Perjanjian Baru (Luke [Lukas] 6: 34-35). ${ }^{14}$

a. Kalangan Nasrani

Larangan praktik pengambilan bunga tercantum dalam kitab Perjanjian Baru yaitu pada Lukas 6: 34-35 yang berbunyi sebagai berikut:

"Dan, jikalau kamu meminjamkan sesuatu kepada orang karena kamu berharap akan menerima sesuatu darinya, apakah jasamu? Orang-orang berdosapun meminjamkan kepada orang berdosa suapaya mereka menerima kembali sama banyak. Tetapi kamu, kasihlah musuhmu dan berbuatlah baik kepada mereka dan pinjamkan dengan tidak mengharapkan balasan, maka upahmu akan besar dan kamu akan menjadi anak-anak Tuhan Yang Maha Tinggi sebab ia baik terhadap orang-orang yang tidak tahu berterima kasih dan terhadap orang-orang jahat."

Selain itu, terdapat pula larangan pengambilan bunga dalam undangundang oleh gereja (canon) yaitu Council of Vienne (1311) sebagai berikut:

"Barang siapa yang menganggap bahwa bunga itu adalah sesuatu yang tidak berdosa maka ia telah keluar dari Kristen."

Council of Vienne (1311) merupakan larangan terhadap bunga yang berlaku umum. Sedangkan sebelumnya ada pula undang-undang serupa tetapi berlaku untuk pihak gereja.

Council of Elvira (Spanyol tahun 306) mengeluarkan Canon 20 yang melarang para pekerja geraja mempraktikkan pengambilan bunga. Barang siapa yang melanggar, pangkatnya akan diturunkan. Council of Arles (tahun 314) mengeluarkan Canon 44 yang juga melarang pekerja gereja mempraktikkan pengambilan bunga. First Council of Nicaea (tahun 325)

\footnotetext{
${ }^{13}$ Andri Soemitra, Bank dan Lembaga Keuangan Syariah (Jakarta: Kencana, 2009), 62-3.

${ }^{14}$ Adiwarman A. Karim, Ekonomi Islam: Suatu Kajian Kontemporer (Jakarta: Gema Insani, 2001), 72.
} 
mengeluarkan Canon 17 yang mengancam akan memecat para pekerja gereja yang memperaktikkan bunga.

Akan tetapi, pada akhir abad ke-13 pengaruh gereja ortodoks mulai melemah dan orang mulai kompromi dengan riba. Bacon, seorang tokoh saat itu dalam tulisannya "Discousre on usury" mengatakan, "Karena kebutuhannya harus meminjam uang dan pada dasarnya manusia enggan hatinya untuk meminjamkan uang kecuali dia akan menerima suatu manfaat dari pinjaman itu, maka bunga harus diperbolehkan."15. Berbagai pandangan kalangan pemuka agama Kristen dapat dikelompokkan menjadi tiga periode utama, yaitu pandangan para pendeta awal Kristen (abad I-XII) yang mengharamkan bunga, pandangan para sarjana Kristen (XII-XVI) yang berkeinginan agar bunga diperbolehkan, dan pandangan para reformis Kristen (abad XVI-tahun 1836) yang menyebabkan agama Kristen menghalalkan bunga (Antonio, 2009: 45-46).

b. Kalangan Yahudi

Orang-orang Yahudi dilarang mempraktikkan pengambilan bunga. Pelarangan ini banyak terdapat dalam kitab suci mereka, baik dalam Old Testament (Perjanjian Lama) maupun undang-undang Tallmud. ${ }^{16}$

"Jika engkau meminjamkan uang kepada salah seorang dari umat-Ku, orang yang miskin diantaramu, maka janganlah engkau berlaku sebagai penagih utang terhdap dia, jnganlah engkau bebankan bunga uang terhadapnya."(Kitab Exodus [Keluaran] pasal 22 ayat 25)

"Janganlah engkau membungakan kepada saudaramu, baik uang maupun bahan makanan, atau apapun yang dapat dibungakan." (Kitab Deuteronomy [Ulangan] pasal 23 ayat 19)

"Janganlah engkau mengambil bunga uang atau riba darinya, melainkan engkau harus takut akan Allahmu, supaya saudaramu bisa hidup di antaramu. Janganlah engkau memberi uangmu kepadanya dengan meminta bunga, juga makananmu janganlah kau berikan dengan meminta riba." (Kitab Levictus [Imamat] pasal 25 ayat 36-37)

Namun orang Yahudi beranggapan bahwa riba itu hanyalah terlarang

\footnotetext{
15 Ibid.

${ }^{16}$ Muhammad Syafi'i Antonio, Bank Syariah: dari teori ke praktik (Jakarta: Gema Insani, 2009), 46.
} 
Muhammad Syarif Hidayatullah

kalau dilakukan di kalangan Yahudi sesama Yahudi, tetapi tidak terlarang dilakukan terhadap non Yahudi. Hal ini disebutkan di dalam kitab Ulangan ayat 20 pasal 23. Tetapi Islam menganggap bahwa ketetapan-ketetapan yang mengharamkan riba yang hanya berlaku pada golongan tertentu, sebagaimana tercantum dalam Perjanjian Lama merupakan ketetapan yang telah dipalsukan. Sebab riba adalah zhalim dan kezhaliman diharamkan kepada semua orang tanpa pandang bulu. ${ }^{17}$

\section{Konsep Riba dikalangan Hindu dan Budha}

Di antara referensi paling tua mengenai riba adalah yang ditemukan pada naskah keagamaan india kuno sebagaimana disarikan dengan amat baik oleh Jain (1929) dalam karyanya Indigeneous Banking in India. Catatan awal turunnya teks vedic India kuno (2000-1400 SM) dimana pemungut riba (kusidin) disebut berulang kali dan diinterpretasikan sebagai pemberi pinjaman dengan bunga. Hal ini juga ditemukan pada teks Sutra (700-100 SM), serta Jatakas dalam Budha (600-400 SM). Pada masa inilah perasaan jijik pada riba diekspresikan. Misalnya adanya larangan bagi kasta Brahmana dan ksatria meminjamkan uang dengan memungut bunga. ${ }^{18}$

\section{Bunga dalam Perspektif Ahli Filsafat Romawi dan Yunani}

Praktik pembungaan uang merupakan perbuatan tercela yang mendapat cercaan dari para filsuf (ahli filsafat). Diantaranya Plato (427-347 SM) dan Aristoteles (384-322 SM), dua orang filsuf Yunani tersohor yang mengecam praktik pengambilan bunga. Hal demikian juga dilakukan Cato (234-149 SM) dan Cicero (106-43 SM). Mereka mengutuk orang-orang Romawi yang mempraktikkan pengambilan bunga.

Ada dua alasan yang menjadi dasar Plato mengecam praktik pembungaan uang. Pertama, bunga menyebabkan perpecahan dan perasaan tidak puas dalam masyarakat. Kedua, bunga merupakan alat golongan kaya

\footnotetext{
${ }^{17}$ Muhammad, Lembaga-lembaga Keuangan Umat Kontemporer (Yogyakarta: UII Press, 2000), 144.

18 Ali Mutasowifin, 'Menggagas Strategi Pengembangan Perbankan Syariah di Pasar Nonmuslim', Jurnal Universitas Paramadina, vol. 3, no. 1 (2003), 32.
} 
untuk mengeksploitasi golongan Miskin. Sedangkan Aristoteles dalam keberatannya terhadap praktik pembungaan uang ini mengungkapkan bahwa fungsi uang adalah sebagai alat tukar atau medium of exchange. Ditegaskan olehnya bahwa uang bukan alat untuk menghasilkan tambahan melalui bunga. Ia pun menyebut bunga sebagai “uang yang berasal dari uang yang keberadaannya dari sesuatu yang belum tentu pasti terjadi". Oleh karena itu, pengambilan bunga secara tetap merupakan sesuatu yang tidak adil.

Penolakan para filsuf Romawi terhadap praktik pengambilan bunga mempunyai alasan yang kurang lebih sama dengan yang dikemukakan filsuf Yunani. Cicero memberi nasihat kepada anaknya agar menjauhi dua pekerjaan, yakni memungut cukai dan memberi pinjaman dengan bunga. Sedangkan Cato menggambarkan perbedaan antara perniagaan dan memberi pinjaman sebagai berikut: Pertama, perniagaan adalah suatu pekerjaan yang mempunyai risiko, sedangkan memberi pinjaman dengan bunga adalah sesuatu yang tidak pantas.. Kedua, dalam tradisi mereka terdapat perbandingan antara seorang pencuri dan seorang pemakan bunga. Pencuri akan didenda dua kali lipat, sedangkan pemakan bunga akan didenda empat kali lipat.

Berdasarkan uraian di atas, maka dapat diambil benang merah yang dapat dipahami bahwa secara ringkasnya pandangan para filsuf Yunani dan Romawi adalah menganggap bahwa praktik pembungaan uang adalah perbuatan yang tercela (hina dan keji). Pandangan demikian itu juga dianut oleh masyarakat umum pada waktu itu. Kenyataan bahwa bunga merupakan praktik yang tidak sehat dalam masyarakat, merupakan akar kelahiran pandangan tersebut. ${ }^{19}$

\section{Bunga dalam Perspektif Sistem Kapitalis}

Eksistensi bunga dalam pandangan sistem kapitalis dilegitimasi sebagai upah atau imbalan atas sejumlah uang yang dipinjamkan oleh pemilik

${ }^{19}$ Antonio, Bank Syariah, 44-5. 
uang untuk membiayai proyek komersial dan lain sebagainya. Modal uang ini menerima kompensasi (imbalan jasa) yang dihitung berdasarkan rasio persentase pertahun. Kompensasi inilah yang disebut sebagai bunga (interest). Kedudukan bunga dalam masyarakat kapitalis tidak berbeda jauh dari kompensasi yang diterima para pemilik properti tak bergerak atau alat-alat produksi yang mereka terima karena menyewakan properti atau alat-alat milik mereka itu. Ilustrasinya bahwa kita dapat menyewa dan menggunakan sebuah rumah dalam jangka waktu tertentu, kemudian mengembalikannya kepada pemiliknya beserta sejumlah uang yang telah disepakati sebagai biaya sewa. Begitu pula dalam masyarakat kapitalis, dapat meminjamkan sejumlah uang untuk keperluan konsumtif ataupun produktif, lalu mengembalikannya kepada pemiliknya plus sejumlah uang tambahan sebagai kompensasi. ${ }^{20}$

Pandangan seperti diuraikan di atas tidaklah sesuai dengan ajaran Islam. Sistem kapitalis berpandangan bahwa bunga sama dengan biaya sewa atau kompensasi, yang artinya menganggap uang adalah barang atau komoditas dengan prinsip dasarnya time value of money. Pandangan seperti ini bertentangan dengan prinsip ekonomi Islam tentang fungsi uang dan ditolak oleh ajaran Islam, karena dalam Islam uang hanyalah sebagai alat tukar dan bukanlah komoditas yang dapat diperjualbelikan dengan bebas. Dalam ekonomi kapitalis yang berlaku adalah time value of money, sedangkan dalam ekonomi Islam yang berlaku adalah economic value of time.

\section{Bunga dalam Perspektif Hukum Islam}

\section{Riba dalam Islam: Tahapan Pelarangan dan Tipologi dalam Fikih}

Riba secara bahasa berarti az-ziyâdah (bertambah). Selain itu pula juga

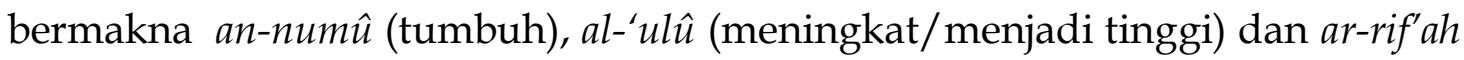
(menjulang). ${ }^{21}$ Sedangkan secara istilah riba adalah pengambilan tambahan

\footnotetext{
${ }^{20}$ Muhammad Baqir ash Sadr, Buku Induk Ekonomi Islam: Iqtishaduna, trans. by Yudi (Jakarta: Zahra, 2008), 370-1.

${ }^{21}$ Jaih Mubarok, 'Riba dalam Transaksi Keuangan', At-Taradhi Jurnal Studi Ekonomi, vol. 6, no. 1 (2015), 3 .
} 
dari harta pokok atau modal secara bathil baik dalam utang-piutang maupun jual beli. ${ }^{22}$ Ada beberapa tahapan dalam pelarangan riba. Riba dan bagianbagian terkait didalamnya, tidaklah diharamkan Allah SWT sekaligus, melainkan bertahap sebagaimana Allah mengharamkan minuman khamar melalui tahapan tahapan. Ada empat tahapan pelarangan riba yakni:23

Tahap pertama, menolak anggapan bahwa pinjaman riba pada zahirnya menambah harta dan menolong mereka yang memerlukan sebagai suatu perbuatan taqarrub (mendekatkan diri) kepada Allah SWT. Ayat terkait yakni QS. $\operatorname{ar}-\mathrm{R} \hat{u} m$ (30): 39. Riba ditekankan sebagai suatu tindakan negatif, walaupun di mata manusia ada yang menilainya positif. Jadi dengan ini mematahkan paradigma manusia bahwa riba bisa melipatgandakan harta. Maka dalam hal ni mengubah persepsi.

Tahap kedua, Kecaman Allah terhadap yang ditujukan kepada orang Yahudi yang masih tetap menjalankan praktik riba. Ayat terkait yakni QS. anNisâ (4): 160-161. Riba digambarkan sebagai suatu yang buruk dan balasan yang keras kepada orang Yahudi yang memakan riba. Jadi dengan inipemberitahuan bahwa riba juga diharamkan bagi umat terdahulu sebelum Islam. Maka dalam hal ini memberi contoh nyata.

Tahap ketiga, riba itu diharamkan dengan dikaitkan kepada suatu tambahan yang berlipat ganda. Ayat terkait yakni QS. Ali 'Imrân (3): 130. Pengharaman riba secara tekstual sudah tegas dinyatakan di tahap ini. Namun bentuk pengharamannya masih bersifat parsial, karena pelarangannya masih terbatas pada bentuk riba yang berlipat ganda, sehingga belum merupakan pengharaman secara totalitas kepada seluruh aktivitas ribawi. Jadi dalam hal ini menunjukkan sebagian karakter riba.

\footnotetext{
${ }^{22}$ Abû al Walîd Muhammad bin Ahmad bin Muhammad bin Rusyd al Andalusî, Bidâyah al-Mujtahid wa an-Nihâyah al-Muqtashid, vol. 2 (Beirut: Dâr al-Ma'rifah), 128.

${ }^{23}$ Dulsukmi Kasim Kasim, 'KONDISI SOSIO-HISTORIS DIBALIK TEKS PENGHARAMAN RIBA DAN IMPLIKASINYA TERHADAP PEGAWAI BANK KONVENSIONAL', Hukum Islam, vol. 20, no. 1 (2020), 5-8; Elpianti Sahara Pakpahan, 'PENGHARAMAN RIBA DALAM ISLAM', AL-HADI, vol. 4 , no. 2 (2020), 572-5.
} 
Tahap keempat (terakhir), ayat riba diturunkan oleh Allah SWT yang dengan jelas dan tegas mengharamkan apapun jenis tambahan yang diambil daripada pinjaman. Ayat terkait yakni QS. al-Baqarah (2): 275-280. Riba telah diharamkan secara total dalam berbagai bentuknya dan digambarkan sebagai sesuatu yang sangat buruk dan tidak layak dilakukan oleh orang-orang Mukmin. Jadi dalam hal ini memberikan hukum dengan tegas dan komprehensif terhadap kedudukan dan status riba dalam transaksi keuangan.

Menurut fuqaha Hanâfiyah, Mâlikiyah dan Hanâbilah, riba terbagi menjadi dua macam, yaitu riba fadhl dan riba nasi'ah. Sedangkan menurut fuqaha Syâfi'îyah, riba terbagi menjadi tiga macam, yaitu riba fadhl, riba nasi'ah, dan riba yad. Dalam jumhur madzâhib, riba yad telah masuk dalam kategori riba nasi'ah. ${ }^{24}$ Selain terminologi riba fadhl, nasi'ah, dan yad, ada pula yang menyebutkan terminologi riba nasa', qardh dan jahiliyyah dalam tipologi riba.

\section{Tabel 1}

Tipologi Riba Menurut Jumhur Ulama

\begin{tabular}{|l|l|l|c|}
\hline \multirow{2}{*}{ Riba } & \multicolumn{1}{|c|}{ Transaksi } & \multicolumn{1}{c|}{ Jenis } & \multicolumn{1}{c|}{ Unsur } \\
\cline { 2 - 4 } & $\begin{array}{l}\text { Pinjam- } \\
\text { meminjam }\end{array}$ & Riba nasi'ah & Penundaan dan tambahan \\
\cline { 2 - 4 } & Jual-beli & Riba fadhl & Tambahan \\
\hline
\end{tabular}

Tabel 2

Tipologi Riba Menurut Fuqaha Mazhab Syafi'i

\begin{tabular}{|l|l|l|l|}
\hline \multirow{2}{*}{ Riba } & \multicolumn{1}{|c|}{ Transaksi } & \multicolumn{1}{|c|}{ Jenis } & \multicolumn{1}{c|}{ Unsur } \\
\cline { 2 - 4 } & $\begin{array}{l}\text { Pinjam- } \\
\text { meminjam }\end{array}$ & Riba nasi'ah & Penundaan dan tambahan \\
\cline { 2 - 4 } & Jual-beli & Riba Fadhl & Tambahan \\
\cline { 3 - 4 } & Riba Yadd & Penundaan \\
\hline
\end{tabular}

Riba nasi'ah dalam Fatwa MUI diartikan tambahan (ziyâdah) tanpa imbalan yang terjadi karena penangguhan pembayaran yang dipersyaratkan

${ }^{24}$ Rachmat Syafe'i, Fiqh Muamalah (Bandung: Pustaka Setia, 2001). 
sebelumnya. ${ }^{25}$ Dalam redaksi lain diartikan penambahan bersyarat dari yang pemberi utang kepada orang yang berutang lantaran penangguhan. ${ }^{26}$ Atau ada pula yang mendefinisikannya penangguhan penyerahan atau penerimaan jenis barang ribawi yang dipertukarkan dengan jenis barang ribawi lainnya. ${ }^{27}$ Dengan demikian, dalam pengertian ini riba nasi'ah dapat disebut juga riba penundaan atau riba utang-piutang (dayn) baik dalam pinjaman uang maupun jual beli.

Lalu riba fadhl adalah tambahan (ziyâdah) atas harta ribawi sejenis yang dipertukarkan (diperjualbelikan). Jadi merupakan pertukaran antarbarang ribawi yang sejenis dengan adanya kelebihan atau tambahan dalam transaksi tersebut. Dalam perspektif Abu Zahrah dan Rafiq Yunus al-Misri, mereka membuat pembagian riba menjadi tiga berbeda dengan jumhur ulama yang membaginya menjadi dua, yakni fadhl dan nasi'ah. Menurut keduanya, riba dibedakan atas riba yang terjadi pada utang-piutang yang disebut dengan riba nasi'ah dan riba yang terjadi pada jual beli, yaitu riba nasa' dan riba fadhl. AlMishri menekankan pentingnya pembedaan antara riba nasi'ah dengan riba nasa' agar terhindar dari kekeliruan dalam mengidentifikasi berbagai bentuk riba. ${ }^{28}$ Sedangkan dalam pengertian riba nasi'ah yang sudah disebutkan sebelumnya, apa yang dimaksud Abu Zahrah dan Rafiq Yunus al-Misri sebagai riba nasa', sudah masuk dalam cakupan pemaknaan riba nasi'ah.

Tabel 3

Tipologi Riba Menurut Abu Zahrah dan Yunus al-Mishri

\begin{tabular}{|c|l|l|l|}
\hline Riba & \multicolumn{1}{|c|}{ Transaksi } & \multicolumn{1}{c|}{ Jenis } & \multicolumn{1}{c|}{ Unsur } \\
\cline { 2 - 4 } & $\begin{array}{l}\text { Pinjam- } \\
\text { meminjam }\end{array}$ & Riba nasi'ah & Penundaan dan tambahan \\
\hline
\end{tabular}

${ }^{25}$ Fatwa MUI No. 1 Tahun 2004 tentang Bunga (interst/fa'idah)

${ }^{26}$ Hasbiyallah, Sudah Syar'ikah Muamalahmu?: Panduan Memahami Seluk-beluk Fiqh Muamalah (Yogyakarta: Salma Idea, 2014), 24.

27 Antonio, Bank Syariah, 93.

28 Moh Syifa 'ul Hisan, 'Riba dan Bunga dalam Kontrak Syariah', SYARIATI, vol. 5, nos. 02, Nov (2019), 2. 
Muhammad Syarif Hidayatullah

\begin{tabular}{|l|l|l|l|}
\hline \multirow{2}{*}{ Jual-beli } & Riba nasa' & Penundaan \\
\cline { 3 - 3 } & Riba fadhl & Tambahan \\
\hline
\end{tabular}

Sedangkan tipologi riba oleh pakar ekonomi syariah asal Indonesia Muhammad Syafi'i Antonio dalam tulisannya menyebutkan bahwa secara garis besar riba dikelompokkan menjadi dua. Masing-masing adalah riba utang-piutang dan riba jual beli. Kelompok pertama terbagi lagi menjadi riba qardh dan riba jahiliyyah. Sedangkan kelompok kedua, riba jual beli, terbagi menjadi riba fadhl dan riba nasi'ah. Adapun penjelasanannya sebagai berikut: (a) riba qardh, yakni suatu manfaat atau tingkat kelebihan tertentu yang disayaratkan terhadap yang berutang (muqtaridh); (b) riba jahiliyyah, yakni utang dibayar lebih dari pokoknya, kerena si peminjam tidak mampu membayar utangnya pada waktu yang ditetapkan; (c) riba fadhl, yakni pertukaran antarbarang yang sejenis dengan kadar yang takaran yang berbeda, sedangkan barang yang dipertukarkan itu termasuk dalam jenis barang ribawi; dan (d) riba nasi'ah, , yakni penangguhan penyerahan atau penerimaan jenis barang ribawi yang dipertukarkan dengan jenis barang ribawi lainnya. ${ }^{29}$

\section{Tabel 4}

Tipologi Riba Menurut Muhammad Syafi'i Antonio

\begin{tabular}{|l|l|l|l|}
\hline Riba & \multicolumn{1}{|c|}{ Transaksi } & \multicolumn{1}{|c|}{ Jenis } & \multicolumn{1}{c|}{ Unsur } \\
\cline { 2 - 4 } & $\begin{array}{l}\text { Pinjam- } \\
\text { meminjam }\end{array}$ & Riba qardh & Penundaan dan tambahan \\
\cline { 3 - 4 } & Jual-beli & Riba Jahiliyah & Penundah \\
\cline { 2 - 4 } & Riba fadhl & Penundaan \\
\hline
\end{tabular}

${ }^{29}$ Antonio, Bank Syariah, 92-3. 
Para ulama telah sepakat tentang haramnya praktik riba, karena telah ditetapkan dengan tegas dan jelas di dalam nash akan keharamannya. Namun pada pembahasan tentang tipologi riba, ada ikhtilâf (perselisihan pendapat). Tipologi riba merupakan hasil ijtihad para ulama, oleh karena itu membuka ruang perbedaan dan keragaman pendapat dalam hal tipologi maupun terminologi yang dipakai sesuai dengan perspektif yang digunakan

\section{Metode Qiyas dalam Istinbâth al-Hukm tentang Bunga Bank}

Qiyas merupakan salah satu metode ijtihad atau metode penemuan hukum (istinbath al-hukm) dalam kajian ushul fikih. Qiyas pula merupakan dalil hukum yang disepakati oleh jumhur ulama setelah al-Qur'an, sunnah dan ijma'. Qiyas menurut Fakhruddîn ar-Râzî adalah penalaran tentang penetapan perumpamaan bentuk hukum pada bentuk yang lain karena terdapat persamaan 'illat hukum ketika menetapkannya. ${ }^{30}$ Sedangkan menurut 'Abdul Wahhâb Khallâf, qiyas adalah menyamakan suatu hukum dari kasus yang tidak memiliki nash hukum dengan kasus yang sudah memiliki nash hukum, sebab adanya persamaan dalam 'illat hukumnya. ${ }^{31}$ Ada empat rukun qiyas yang harus dipenuhi dalam pengaplikasiannya, yakni:32

1) al-ashl (الاصل) yaitu sesuatu yang ada hukumnya dalam nash. Disebut maqis 'alaih (yang dijadikan ukuran), atau mahmul 'alaih (yang dijadikan pertanggungan), atau musyabbah bih (yang dibuat keserupaan/yang menyerupakan).

2) al-far' (الفرع) yaitu sesuatu yang tidak ada hukumnya dalam nash, tetapi ada maksud menyamakannya kepada al-ashl dalam hukumnya. Disebut al-maqis (yang diukur), atau al-mahmul (yang dibawa) atau musyabbah (yang diserupakan).

\footnotetext{
${ }^{30}$ Fakhruddîn Muhammad bin 'Umar bin al-Husain ar Râzî, al-Ma'âlim fî̀ 'Ilm Ushûl al-Fiqh (Kairo: Dâr al-Ma'rifah, 1994).

31 'Abdul Wahhâb Khallâf, 'Ilm Ushûl al-Fiqh (Kairo: Maktabah ad-Da'wah al-Islâmiyyah Syabâb alAzhar), 52.

${ }^{32}$ Ibid., 60.
} 
3) hukm al-ashl (حكم الاصل) yaitu hukum syara' yang ada nashnya menurut ashl (pokok) dan dimaksud dengan ini sebagai pangkal hukum bagi far' (cabang.).

4) al-illat (العلة) yaitu keadaan yang dijadikan dasar oleh hukum ashl (pokok) berdasarkan wujudnya keadaan itu pada cabang, maka disamakanlah cabang itu kepada pokok mengenai hukumnya.

Memahami bunga bank dari aspek legal-formal dan secara induktif, berdasarkan pelarangan terhadap larangan riba yang diambil dari teks (nash) dan tidak perlu dikaitkan dengan aspek moral dalam pengharamannya. Paradigma ini berpegang pada konsep bahwa setiap utang-piutang yang disyaratkan ada tambahan atau manfaat dari modal adalah riba, walaupun tidak berlipat ganda. Oleh karena itu, betapapun kecilnya, suku bunga bank tetap haram. ${ }^{33}$ Berdasarkan pendekatan qiyas, maka praktik riba sebagai ashl dan bunga bank sebagai far', keduanya disatukan dalam 'illat yang sama yaitu adanya tambahan tanpa disertai imbalan. ${ }^{34}$ Maka sebagaimana riba yang hukumnya haram, maka seperti itu juga hukum bunga bank yakni haram.

\section{Bunga Bank dan Riba}

Bunga (Interest) yaitu imbalan yang dibayar oleh peminjam atas dana yang diterimanya, bunga dinyatakan dalam persen. ${ }^{35}$ Dalam praktik dimasyarakat secara individu, pemberian pinjaman uang dengan adanya tambahan dalam pengembaliannya biasa dilakukan oleh orang yang dikenal dengan profesi rentenir (lintah darat). Tambahan ditetapkan diawal saat berlangsungnya transaksi antara kreditur (orang yang berpiutang/pemberi pinjaman uang) dengan debitur (orang yang berutang/penerima pinjaman uang). Misalkan: si A meminjam uang kepada si B sebesar Rp. 1.000.000,

\footnotetext{
33 Muhammad Syarif Hasyim, 'BUNGA BANK: ANTARA PARADIGMA TEKSTUAL DAN KONTEKSTUAL', HUNAFA: Jurnal Studia Islamika, vol. 5, no. 1 (2008), 51.

${ }^{34}$ Mohammad Mufid, Ushul Fiqh Ekonomi dan Keuangan Kontemporer: Dari Teori Ke Aplikasi (Jakarta: Kencana, 2016), 75.

${ }^{35}$ Erwandi Tarmizi, Harta Haram Muamalat Kontemporer (Bogor: Berkat Mulia Insani, 2013), 350.
} 
kemudian si B mensyaratkan pembayaran utang tersebut nantinya dengan bunga sebesar 10\%, maka ketika pengembalian uang si A diwajibkan untuk membayar utangnya yang jumlah aslinya adalah Rp. 1.000 .000 akhirnya bertambah menjadi Rp. 1.100.000. Jumlah uang Rp. 100.000 sebagai nilai tambah dari utang pokok tersebut merupakan riba.

Untuk praktik bunga di bank, maka dapat dibagi menjadi dua bentuk, yaitu bunga simpanan dan bunga pinjaman. Bunga simpanan merupakan bunga dari produk simpanan yang ada di bank seperti bunga tabungan, bunga deposito, dan penggunaan giro. Sedangkan bunga pinjaman terdapat dalam transaksi kredit. bunga pinjaman selalu lebih besar daripada bunga simpanan, dikarenakan selisih dari bunga pinjaman dan bunga simpanan merupakan keuntungan dari Bank Konvensional, atau dengan kata lain keuntungan tersebut berasal dari bunga pinjaman yang berjumlah lebih besar dikurangkan dengan bunga simpanan yang pastinya memiliki jumlah yang lebih kecil.

Menurut Yûsuf al-Qaradhâwî, bunga yang didapatkan nasabah dari produk simpanan di bank (tabungan, giro, deposito) adalah riba yang dalam syariat Islam status hukumnya adalah haram. Apa yang disebut sebagai riba atau bunga adalah suatu kelebihan yang dipersyaratkan pada pokok modal yang dididapatkan tanpa usaha berniaga (berdagang) dan tanpa susah payah. Tambahan atau kelebihan atas pokok modal yang diperoleh dengan cari seperti itu adalah riba. Yûsuf al-Qaradhâwî pula menjelaskan bahwa bunga merupakan nilai lebih dari pokok modal yang didapatkan tanpa keikutsertaan dalam usaha, tanpa menghadapi kemungkinan rugi, tanpa pendapatan yang fluktuatif dan tanpa kegiatan berjual-beli. ${ }^{36}$

Dengan banyak disuarakannya tentang keharaman bunga bank, akan tetapi masih ada saja pihak yang membolehkan pengambilan bunga dan

\footnotetext{
${ }^{36}$ Yûsuf al Qaradhâwî, Fatwa-fatwa Mutakhir, trans. by H.M.H. al-Hamid al-Husaini (Jakarta: Yayasan al-Hamidiy, 1995), 769-70.
} 
menganggapnya bukan riba dengan pernyataan atau alasan-alasan sebagai berikut: (a) Haram hanya pada bunga konsumtif dan halal pada bunga produktif. Karena pada pinjaman produktif peminjam mengeluarkannya untuk hal-hal yang menguntungkan dan menurut mereka membawa faidah. Jadi pinjaman ini tidak ada sifat pemerasan; (b) Haram hanya riba yang berganda, tidak pada pinjaman yang berbunga kecil; (c) Boleh mengambil bunga dalam keadaan butuh dan untuk kemaslahatan umum; (d) Ada pula yang mengharamkan bunga, tetapi membolehkan menabung di Bank Konvensional asalkan tidak mengambil bunganya.

Dalam hal ini, selanjutnya penulis akan berupaya menanggapi argumentasi di atas yang dijadikan landasan dalam upaya melegalkan praktik pembungaan uang.

\section{Tanggapan terhadap argumentasi poin a}

1) Pendapat ini berupaya melegalisasi bunga utang-piutang atau dengan kata lain berupaya menghalalkan praktik pembungaan uang yang dihubungkan dengan tujuan penggunaan melalui pandangan bahwasanya riba pada utang berbunga hanya berlaku pada pinjaman konsumtif, sedangkan untuk pinjaman produktif dalam hal bisnis bukanlah riba. Jadi asumsi ini beranggapan bahwa keharaman riba pada utang-piutang hanya berlaku dalam piutang yang digunakan debitur untuk kebutuhan konsumsi, sedangkan piutang yang digunakan debitur untuk kebutuhan produksi atau perniagaan (operasional bisnis) tidak berlaku. Pendapat ini dibantah oleh Rafîq Yûnus al Mishrî dengan menyatakan bahwa penuturan kata riba pada utang-piutang dalam nash bersifat universal, baik utang untuk konsumsi maupun produksi dan perniagaan. Tidak ada spesifikasi tertentu dalam mengkategorikan keharaman riba utang-piutang. Begitu pula sikap para ulama dari zaman Nabi Muhammad saw. hingga saat ini tidak membedakan antara utang untuk konsumsi, produksi dan perniagaan. Status ketiganya adalah sama, yaitu transaksi tabarru' yang tidak 
diperkenankan untuk mengampil keuntungan walaupun hanya sedikit darinya. ${ }^{37}$ Keputusan Muktamar Islam II Lembaga Riset Islam yang diselenggarakan di Kairo pada Muharram 1385 H juga menjelaskan demikian, bahwa bunga (interest) dari semua jenis pinjaman, hukumnya riba yang diharamkan dan tidak ada pembedaan antara "pinjaman konsumtif" dan "pinjaman produktif", serta banyak maupun sedikit sama haramnya. ${ }^{38}$ Selain itu, Muktamar Bank Islam II di Kuwait pula menekankan dalam keputusannya bahwa apa yang disebut dengan interest menurut istilah ekonom Barat dan pengikut-pengikut mereka merupakan riba yang diharamkan secara syariat. ${ }^{39}$

2) Menurut Yûsuf al-Qaradhâwî, riba yang diharamkan dalam al-Quran tidak membutuhkan penjelasan dan pembahasan lebih lanjut, karena tidak mungkin Allah mengharamkan sesuatu kepada manusia yang tidak mereka ketahui bentuknya. Pemahaman riba sesuai yang tertuang dalam Q.S AlBaqarah/2:278-279 menunjukkan segala kelebihan dari pokok utang adalah riba, sedikit maupun banyak. Maka setiap tambahan bagi pokok utang yang disyaratkan atau ditentukan terlebih dahulu, karena adanya unsur tenggang waktu semata adalah riba. ${ }^{40}$

3) Syariat Islam mengharamkan setiap keuntungan yang dikeruk dari piutang/pinjaman uang, dan menyebutnya sebagai riba. Oleh karenanya para ulama menegaskan hal ini dalam sebuah kaidah yang sangat masyhur, yaitu: 41

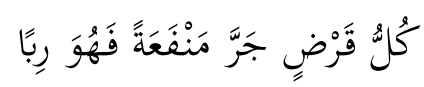

"Setiap pinjaman uang yang mendatangkan manfaat maka itu adalah riba."

Kategori manfaat yang diterangkan pada kaidah fiqih di atas maksudnya bukan manfaat secara general sehingga mencakup seluruh manfaat yang

${ }^{37}$ Rafî̀ Yûnus al Mishrî, Ribâ al-Qurûdh wa Adillah Tahrîmih (Damaskus: Dâr al-Maktabî, 2009), 33.

${ }^{38}$ Yûsuf al Qaradhâwî, Fawâ'id al-Bunûk hiya al-Ribâ al-Harâm (Kairo: Dâr al-Shahwah, 1994), 130.

${ }^{39}$ Ibid., 145.

${ }^{40}$ al Qaradhâwî, Fawấ 'id al-Bunûk hiya al-Ribâ al-Harâm.

41 Tarmizi, Harta Haram Muamalat Kontemporer, p. 398. 
ada dalam transaksi pinjaman tersebut. sepertihalnya dalam perspektif si peminjam, maka ada manfaat yang ia dapatkan dalam transaksi pinjaman tersebut yakni ia memperoleh manfaat yang terwujud pada terbantunya ia dalam mencukupi kebutuhan hidupnya atau tambahan modal untuk usaha mengembangkan bisnisnya, maka bukan manfaat demikian yang dimaksud oleh kaidah fiqih ini. Erwandi Tarmizi menyebutkan kriteria manfaat (keuntungan) dari akad pinjaman yang dianggap riba yakni:

a) Keuntungan yang terpisah dan bukan keuntungan yang mengikut dalam akad pinjaman. Maka keuntungan yang bersifat mengikuti tidak diharamkan, seperti: seseorang yang memberikan pinjaman kepada pihak lain, terlebih pihak tersebut mapan secara ekonomi dan tidak menundanunda pembayaran pinjaman maka pemberi pinjaman mendapat keuntungan dalam bentuk uangnya aman dari hal-hal yang tidak diinginkan.

b) Keuntungan hanya dinikmati oleh pemberi pinjaman. Bila keuntungan yang disebabkan oleh akad pinjaman yang disyaratkan di awal akad adalah untuk peminjam, hukumnya boleh. Karena pemberi pinjaman berarti menambah kebajikannya terhadap peminjam yang biasanya adalah orang yang sangat membutuhkan.

c) Keuntungan yang dinikmati pemberi pinjaman disyaratkan diawal akad. Bila tidak disyaratkan di awal akad, akan tetapi pada saat pelunasan utang peminjam memberikan hadiah baik dalam bentuk yang sejenis ataupun tidak, maka hukumnya boleh.

Setiap piutang yang dipersyaratkan padanya suatu hal yang akan mendatangkan kemanfaatan bagi pemberi piutang maka itu adalah riba. Bila ada orang yang melakukan hal itu, maka akad utang-piutangnya batal, bila persyaratan itu terjadi pada saat akad berlangsung. ${ }^{42}$

\footnotetext{
${ }^{42}$ Muhammad Arifin Badri, Riba dan Tinjauan Kritis Perbankan Syariah (Bogor: Darul Ilmi, 2012), 111.
} 
Sebenarnya terdapat hadits yang serupa dengan kaidah fiqih muamalah ini yang diriwayatkan oleh Hârits bin Usâmah. ${ }^{43}$ Hadits ini sebagaimana disebutkan Ibnu Hajar al 'Asqalânî dalam Bulûgh al-Marâm, bahwa sanadnya terputus. ${ }^{4}$ Hadits ini punya penguat dengan hadits dari sahabat Nabi, Fadhâlah bin 'Ubaid dikeluarkan oleh al-Baihaqî dengan redaksi berikut: 45

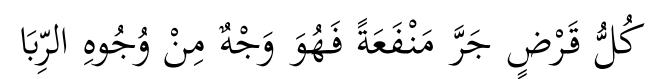

"Setiap pinjaman uang yang mendatangkan manfaat maka itu adalah wajah daripada wajahnya riba."

Meskipun hadits di atas dha'if(lemah), namun kandungannya dapat dikategorikan shahih atau benar karena dikuatkan oleh kesepakatan para ulama dan kaidah fiqih yang maknanya selaraspun telah menjadi kaidah fiqih yang masyhur dikalangan para ulama. Ibnu Qudâmah dalam al-Mughnî menyebutkan: ${ }^{46}$

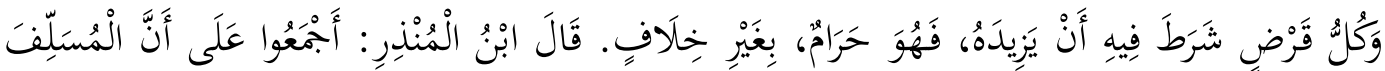

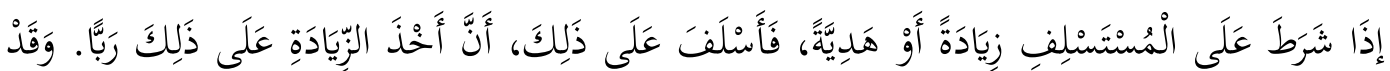

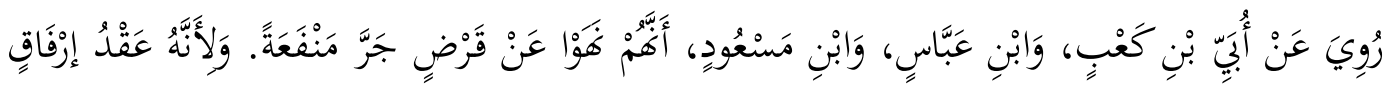

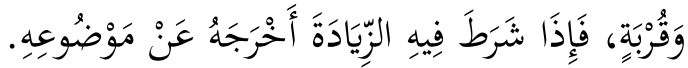

Setiap qardh (pinjaman uang/utang-piutang) yang mensyaratkan penambahan hukumnya haram tanpa ada khilaf (diperselisihkan). Ibnu munzir berkata: mereka (para ulama) ber-ijma' (sepakat/konsensus) bahwasanya jika orang yang memberikan pinjaman memberikan syarat kepada yang meminjam supaya memberikan tambahan atau hadiah, maka tambahan tersebut hukumnya riba. Dan telah diriwayatkan dari ubay bin ka'ab, Ibnu Abbas dan ibnu Mas'ud mereka melarang pinjaman uang yang memberikan manfaat/keuntungan, karena pinjaman uang adalah bersifat sosial dan ingin cari pahala. Jika di dalamnya disengaja mencari keuntungan, maka sudah keluar dari konteks tujuannya.

\footnotetext{
${ }^{43}$ Abû Muhammad al Hârits bin Muhammad bin Dâhir at Tamîmî al Baghdâdî al Khushaib al Ma'rûf bin Abî Usâmah, Bughyah al-Bâhits 'an Zawâid Musnad al-Hârits, vol. 1 (Madinah Munawwarah: Markaz Khidmah as-Sunnah wa as-Sîrah an-Nabawiyah, 1992), 500.

44 Abu al Fadhl Ahmad bin 'Alî bin Hajar al 'Asqalânî, Bulûgh al-Marâm min Adillat al-Ahkâm (Riyadh: Dâr al-Falaq, 1424), 253.

45 Abû Bakar Ahmad bin al Husain bin 'Alî bin 'Abdullah bin Mûsa al Khusraujirdî al Baihaqî, asSunan al-Kubrâ, vol. 5 (Beirut: Dâr al-Kutub al-'Ilmiyah, 2003), 573.

${ }^{46}$ Muwaffaquddîn Abû Muhammad 'Abdullah bin Ahmad bin Muhammad bin Qudâmah al Maqdisî, alMughnî, vol. 4 (Kairo: Maktabah al-Qâhirah, 1968), 240.
} 
Ibnu Qudâmah memberikan catatan:47

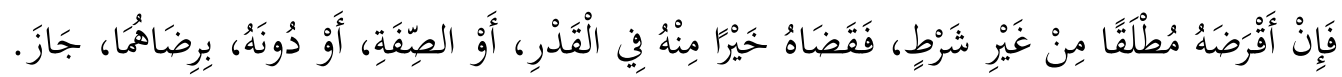
Dan jika meminjamkan secara mutlak tanpa syarat apapun (syarat penambahan di awal), kemudian dikembalikan dengan yang lebih baik secara ukuran (jumlah berlebih), sifat atau yang lainnya dengan keridhaan keduanya, maka dibolehkan.

4) Bunga ditetapkan diawal dan sifatnya tetap (fix). Misalkan 5\%, 10\%, dan lain-lainnya. Mau bunga konsumtif ataupun bunga produktif keduanya tetaplah haram. Pada pinjaman produktif, berapa jumlah keuntungan yang ia dapatkan baik banyak ataupun sedikit, dengan ketentuan bunga yang sifatnya tetap, maka pengembalian tidak berubah. Ketika peminjam mendapatkan untung sangat banyak, tetapi hanya memberikan bagian sedikit kepada pemilik uang, perbuatan semacam itu juga dapat dikategorikan sebagai perbuatan yang termasuk pemerasan dan zhalim. Jelas hal itu haram, karena riba, sebagaimana yang dijelaskan oleh Syekh Abu Sura'i Abdul Hadi. ${ }^{48}$ Ketika peminjam uang (debitur) mangalami kerugian dalam bisnisnya dan tetap diharuskan menyerahkan sejumlah uang tambahan yang merupakan bunga dengan ketentuan diawal dan tetap kepada yang meminjamkan (kreditur), maka telah menyalahi kaidah

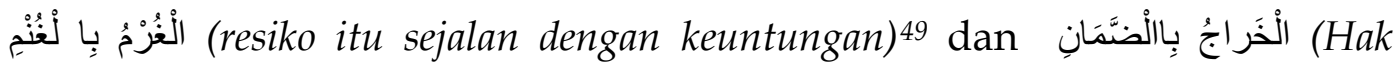
mendapat hasil itu sebagai ganti kerugian [yang ditanggung]) 50 dimana artinya untung itu muncul bersama resiko dan hasil usaha muncul bersama biaya, dengan begitu transaksi tadi adalah praktik riba. Operasional perbankan yang dibenarkan untuk mendapatkan keuntungan adalah melalui transaksi mudharabah dengan nisbah bagi hasil berdasar persentase yang jumlahnya sesuai mengikuti keuntungan yang didapatkan oleh pengelola (mudharib).

Pada tahun 1965 dalam muktamar Islam ke-2 di kairo yang dihadiri oleh

\footnotetext{
${ }^{47}$ Ibid., 4: 241.

${ }^{48}$ Abu Sura'i Abdul Hadi, Bunga Bank dalam Islam, trans. by M. Thalib (Surabaya: al-Ikhlas, 1993).

${ }^{49}$ Fathurrahman Azhari, Qawaid Fiqhiyyah Muamalah (Banjarmasin: Lembaga Pengembangan Kualitas Umat, 2014), 258.

${ }^{50}$ Ibid., 241.
} 
150 ulama dari 35 negara Islam telah diputuskan:

"Bunga Bank dalam segala bentuknya adalah pinjaman yang bertambah. Hukumnya adalah haram, karena termasuk riba. Tidak ada perbedaan antara pinjaman konsumtif atau produktif. Riba diharamkan, baik persentasenya banyak maupun sedikit. Dan akad pemberian pinjaman yang disertakan dengan bunga juga diharamkan."

Pada tahun 1985 M, Majma' al-Fiqh al-Islami (divisi fiqih OKI) mengadakan muktamar yang dihadiri oleh ulama perwakilan negara-negara anggota OKI memutuskan:

"Setiap penambahan dalam pengembalian utang, atau bunga, atau denda karena keterlambatan pelunasan utang, begitu juga bunga yang ditetapkan persennya sejak dari awal transaksi, hal ini adalah riba yang diharamkan syari'at Islam."

5) Seperti dijelaskan sebelumnya pula, bunga dalam perspektif sistem kapitalis dianggap sama seperti kompensasi atau biaya sewa. Jika dikatakan disewa, artinya menganggap uang sebagai komoditas, sedangkan dalam Islam uang hanyalah alat tukar bukanlah komoditas, yang artinya tidak dapat disewakan. Dengan begitu bunga tidak dibenarkan dalam Islam. Dalam tinjauan sosio-ekonomi, Ekonom kontemporer muslim Muhammad Umer Chapra menilai bunga bank dengan menyebut bahwa praktik bunga bank akan semakin memperlebar jarak pemisah (kesenjangan) antara si kaya dan si miskin. ${ }^{51}$

6) Syekh 'Abdullah al-Bassâm dalam Taisîr al-'Allâm Syarah 'Umdah al-Ahkâm menuliskan: ${ }^{52}$

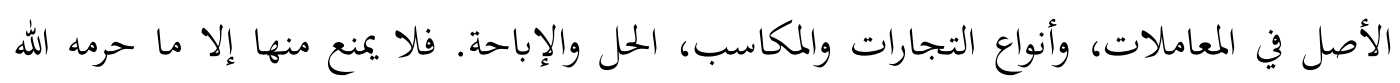

hukum asal muamalah, jenis perdagangan dan keuntungan adalah halal dan boleh.

Maka tidak dilarang darinya kecuali apa yang dilarang oleh Allah dan RasulNya.

\footnotetext{
${ }^{51}$ Abdul Qodir Zaelani, 'Bunga Bank dalam Perspektif Sosio-Ekonomi dan Ushul Fiqh (Studi Atas Pemikiran M. Umer Chapra)', ASAS, vol. 4, no. 2 (2012).

52 Abû 'Abdurrahmân 'Abdullah bin 'Abdurrahmân bin Shâlih bin Hammad bin Muhammad bin Hammad al-Bassâm, Taisîr al-'Allâm Syarah 'Umdah al-Ahkâm (Beirut: Maktabah at-Tâbi'în, 2006), 449.
} 
Islam tidaklah melarang untuk mencari keuntungan dalam bisnis, karena hukum asal bisnis dan keuntungan yang ada didalamnya adalah halal dan boleh, akan tetapi yang perlu diperhatikan adalah menggunakan akad yang memang sifatnya akad bisnis/komersial (tijârah) dan identifikasi bahwa tidak ada unsur terlarang dalam operasionalnya. Pada dasarnya akad yang digunakan bank konvensional dalam praktik pembungaan uang adalah akad qardh (utang-piutang/pinjaman uang) merupakan akad tathawwu'i, yakni akad saling membantu dan bukan transaksi komersial, ${ }^{53}$ jadi sifatnya sosial dan murni tolong-menolong. Inilah kesalahan mendasar bank konvensional yang menjadikan akad qardh sebagai akad bisnis. Keuntungan yang dipersyaratkan dan ditarik dari akad qardh dengan apa yang disebut bank sebagai bunga adalah riba yang hukumnya haram. Untuk dapat menjalankan bisnis maka dapat menarik keuntungan yang halal dan dibolehkan seperti ujrah pada akad ijârah (sewamenyewa/upah-mengupah), margin keuntungan dalam akad bai' (jual beli) dan bagi hasil dalam akad syirkah (kerja sama).

7) Ijmâ' (konsensus/kesepakatan) tentang keharaman bunga bank. Menurut Syekh Yûsuf al-Qaradhâwî bahwa sebanyak 300 ulama dan pakar ekonomi dunia telah menghasilkan suatu ijma' tentang keharaman bunga bank (mereka terdiri dari ahli fikih, ahli ekonomi dan keuangan dunia) melalui satu pertemuan di mana telah lahir ijma' ulama dari berbagai lembaga, pusat penelitian, muktamar, seminar-seminar ahli fikih dan ahli ekonomi Islam yang mengharamkan bunga bank dalam segala bentuknya dan bunga bank itu adalah riba tanpa diragukan lagi. ${ }^{54}$ Selain Majelis Ulama Indonesia (MUI) yang telah mengeluarkan fatwa haramnya bunga bank, ketetapan akan keharaman bunga bank juga dikeluarkan oleh berbagai Forum Ulama

\footnotetext{
${ }^{53}$ Ismail Nawawi, Fikih Muamalah Klasik dan Kontemporer (Bogor: Ghalia Indonesia, 2012), 178.

${ }^{54}$ Fathurrahman Azhari, Ushul Fiqh Ekonomi dan Keuangan Syariah (Depok: RajaGrafindo Persada, 2019), 90-1.
} 
skala regional maupun Internasional antara lain: Majmấ al-Buhûts alIslâmiyyah di al-Azhar Mesir pada Mei 1965, Majmâ' al-Fiqh al-Islâmî Negaranegara OKI yang diselenggarakan di Jeddah tgl 10-16 Rabi'ul Awal 1406 H/22-28 Desember 1985, Majmâ' Fiqh Rabithah al-'Alam al Islâmî Keputusan 6 Sidang IX yang diselenggarakan di Makkah tanggal 12 - 19 Rajab 1406 H, Keputusan Dâr al-Ifta, Kerajaan Saudi Arabia, 1979, Keputusan Supreme Shariah Court Pakistan 22 Desember 1999, Keputusan Muktamar kedua tentang ekonomi Islam di Kuwait pada tahun 1403 H/1983 M dan Keputusan Majma' Fiqih Islam di India pada bulan Jumadil awal $1410 \mathrm{H}$.

\section{Tanggapan terhadap argumentasi poin $b$}

1) Mereka yang berpendapat demikian mengacu pada QS. Ali Imrân (3): 130

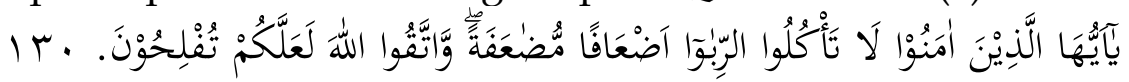

"Hai orang-orang yang beriman, janganlah kamu memakan Riba dengan berlipat ganda dan bertakwalah kamu kepada Allah supaya kamu mendapat keberuntungan."

Orang yang membatasi haramnya riba pada riba berganda, titik tolak alasannya tidaklah benar. Karena ayat bersangkutan berbicara tentang tahapan lahirnya pengharaman riba. ${ }^{55}$ Dalam ayat di atas tidak ada penjelasan bahwa riba hanyalah yang berlipat ganda, bahkan sebaliknya di ayat yang lain (QS. al-Baqarah/2: 279) Allah menjelaskan bahwa bila seseorang bertaubat dari riba, ia hanya boleh menarik jumlah uang yang ia pinjamkan dan tidak boleh lebih dari itu. ${ }^{56}$

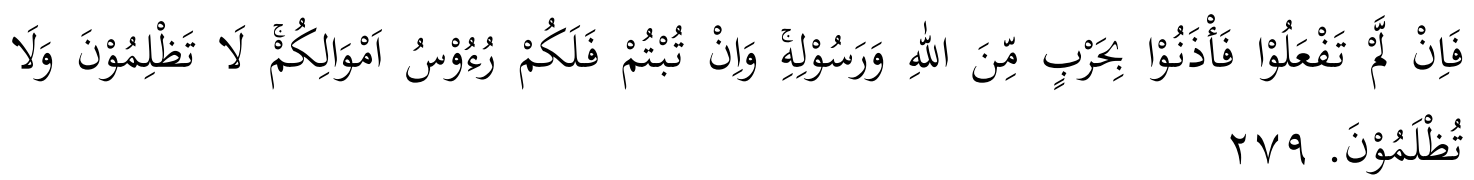

"Maka jika kamu tidak mengerjakan (meninggalkan sisa riba), Maka ketahuilah, bahwa Allah dan Rasul-Nya akan memerangimu. dan jika kamu bertaubat (dari pengambilan riba), Maka bagimu pokok hartamu; kamu tidak Menganiaya dan tidak (pula) dianiaya."

2) Wahbah az Zuhailî dalam al-Fiqh al- Islâmî wa Adillatuh menyampaikan: ${ }^{57}$

\footnotetext{
${ }^{55}$ Hadi, Bunga Bank dalam Islam, 219.

56 Tarmizi, Harta Haram Muamalat Kontemporer, 353.

${ }^{57}$ Wahbah az Zuhailî, al-Fiqh al-Islâmî wa Adillatuh, vol. 5 (Damaskus: Dar al-Fikr), 3741-5.
} 


$$
\begin{aligned}
& \text { فوائد المصارف (البنوك) حرام حرام حرام... وربا المصارف أو فوائد البنوك: من ربا النسيئة، سواء أكانت } \\
& \text { الفائدة بسيطة أم مركبة، لأن عمل البنوك الأصلي الإقراض والاقتراض... وإن مضار الربا في فوائد البنوك } \\
& \text { متحققة تماماً، وهي حرام حرام حرام كالربا وإثمها كإثمه، لقوله تعالى: }
\end{aligned}
$$

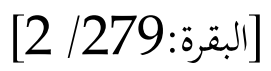

Bunga bank adalah haram, haram, haram... Riba bank atau bunga bank adalah riba nasi'ah, baik bunga tersebut rendah maupun berganda. (hal itu) karena kegiatan utama bank adalah memberikan utang (pinjaman) dan menerima utang (pinjaman)... Bahaya (mudharat) riba terwujud sempurna (terdapat secara penuh) dalam bunga bank. Bunga bank hukumnya haram, haram, haram sebagaimana riba. Dosa (karena bertransaksi) bunga sama dengan dosa riba; alasan lain adalah firman Allah SWT, "dan jika kamu bertaubat (dari pengambilan riba), maka bagimu pokok hartamu...(QS. al-Baqarah/2: 279).

3) Menurut Agustianto, seorang pakar ekonomi dan keuangan syariah yang juga anggota Pleno DSN-MUI, bahwasanya ada yang menganggap bahwa 'illat riba adalah zhulm atau perbuatan zhalim. Padahal 'illatnya bukanlah zhulm. Kesalahan menemukan 'illat riba akan mengakibatkan kekeliruan selanjutnya, seperti menganggap bahwa suku bunga yang rendah misalkan dua atau tiga persen saja itu bukanlah riba karena ringan dan dianggap tidak zhulm dibandingkan dengan margin murâbahah yang mencapai sepuluh sampai dua belas persen setahun.

4) Sebagaimana yang disebutkan dalam fatwa MUI bahwa Bunga uang atas pinjaman (qardh) yang berlaku di atas lebih buruk dari riba yang diharamkan Allah SWT dalam al-Qur'an, karena dalam riba tambahan hanya dikenakan pada saat si peminjam (berhutang) tidak mampu mengembalikan pinjaman pada saat jatuh tempo. Sedangkan dalam sistem bunga tambahan sudah langsung dikenakan sejak terjadi transaksi.

\section{Tanggapan terhadap arguemntasi poin $c$}

1) Tujuan Allah swt. mensyariatkan hukumnya adalah untuk memelihara kemaslahatan manusia sekaligus untuk menghindari mafsadat, baik di dunia maupun di akhirat. Tujuan tersebut hendak dicapai melalui taklif yang pelaksanaannya tergantung pada penalaran sumber hukum utama 
yaitu al-Quran dan Hadits. ${ }^{58}$ Tujuan mengadakan akad pula dalam bermuamalah pada dasarnya adalah untuk mencapai kemaslahatan bagi masing-masing pihak yang mengadakan akad. ${ }^{59}$ Pengertian maslahat dalam Islam meliputi dimensi kebahagiaan dunia dan akhirat. Maslahat merupakan aspek yang menjadi tujuan disyariatkannya suatu hukum (maqâshid asy-syarî'ah). Fathi ad-Dâraynî menyatakan bahwa hukum-hukum tidaklah dibuat untuk hukum itu sendiri melainkan dibuat untuk tujuan kemaslahatan. ${ }^{60}$ Berkaitan dengan aspek maslahat, Imam al-Izz bin 'Abd asSalâm menyatakan bahwa syariat itu semuanya maslahat baik menolak kejahatan maupun menarik kebaikan. ${ }^{61}$ Dalam hal ini Imam asy-Syatibi yang dikenal sebagai Bapak maqâshid asy-syarî'ah dengan karya monumentalnya Kitab al-Muwâfaqât mengatakan bahwasanya syariat itu ditetapkan bertujuan untuk tegaknya kemaslahatan manusia di dunia dan akhirat. ${ }^{62}$ Oleh karena itu, asy-Syâtibî menegaskan bahwa kemaslahatan tidak diukur oleh hawa nafsu, karena jika sesuatu itu mengandung kemaslahatan dunia tanpa kemaslahatan akhirat, maka itu bukan maslahat. Jadi tolak ukur dari maslahat adalah kembali kepada al-Qur'an dan sunnah sebagai mashâdir al-Ahkâm al-Syar'iyyah, tidak hanya disandarkan kepada akal saja, melainkan akal haruslah didasarkan dan diarahkan oleh syariat, bukan diarahkan bebas tanpa arah apalagi dibangun oleh hawa nafsu belaka.

Kaidah terkait:63

\footnotetext{
${ }^{58}$ Fathurrahman Djamil, Filsafat Hukum Islam (Jakarta: Logos Wacana Ilmu, 1997), 125.

${ }^{59}$ Siti Zafilah Firdausiah Fila, 'Kajian Teoritik Terhadap Urgensi Asas Dalam Akad (Kontrak) Syariah', Al - Muamalat: Jurnal Hukum dan Ekonomi Syariah, vol. 5, no. 1 (2020), 60.

${ }^{60}$ Fathi ad Dâraynî, al-Minhâj al-Ushûliyyah fî Ijtihâd bî ar-Ra'yi fî at-Tasyrî̀' (Damaskus: Dâr alKutub al-Hadîts, 1975), 28.

61 al Izz bin 'Abd as Salâm, Qawâ'id al-Ahkâm fî̀ Mashâlih al-Anâm (Beirut: Dâr al-Kutub al-'Ilmiyah, 2001), 9.

${ }^{62}$ Abû Ishâq Ibrâhîm bin Mûsâ bin Muhammad al-Khamrî al-Gharnâthî asy Syâthibî, al-Muwâfaqât fî̀ Ushûl asy-Syarî'ah, vol. 1 (Kairo: Mustafa Muhammad), 21.

${ }^{63}$ Muhammad Muhammad Ismâ'̂̂l, al-Fikr al-Islâm (Beirut: al-Maktabah al-Wa'î, 1958), 43.
} 


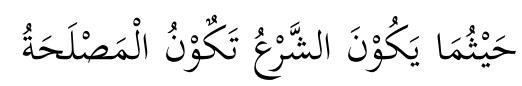

"Apabila hukum syara' dilaksanakan, maka pastilah tercipta kemaslahatan."

2) Kemaslahatan menurut al-Ghazâlî, didapatkan apabila terwujudnya dan terpeliharanya lima unsur pokok, yaitu hifzh ad-dîn (memelihara agama), hifzh an-nafs (memelihara jiwa), hifzh al-'aql (memelihara akal/pikiran), hifzh an-nasb (memelihara keturunan), dan hifzh al-mâl (memelihara harta). ${ }^{64}$

3) Barang siapa membenarkan penerimaan bunga di saat terdesak atau karena kemaslahatn umum, berarti ia secara umum membenarkan adanya bunga pada pinjaman. Karena keadaan terdesak atau butuh selamanya tentu ada, begitu juga kemaslahatan umum. Kita seharusnya membedakan antara darurat dengan keadaan mendesak/butuh. Karena darurat hanya terjadi dalam beberapa saat terbatas. Adapun karena kemaslahatan umum, maka yang sebenarnya haruslah justru tanpa bunga, bukan dengan penarikan bunga. Sebab tidaklah menjadi kemaslahatan umum adanya pengambilan untung dari peminjam dalam keadaan darurat atau pemerasan. 65

\section{Tanggapan terhadap argumentasi d}

1) Bahwasanya menabung di bank, sekalipun dinamakan simpanan, dalam pandangan fikih akadnya memiliki konsekuensi hukum pinjaman. Karena, pinjaman ( ardh) dalam terminologi fiqih berarti menyerahkan uang kepada seseorang untuk dipergunakannya dan dikembalikan dalam bentuk uang senilai pinjaman. Pengertian qardh ini sama dengan tabungan, di mana uang tabungan yang disimpan di bank digunakan oleh bank, kemudian bank mengembalikannya kapan dibutuhkan oleh penabung dalam bentuk penarikan uang tabungan. Bila hakikat menabung di bank adalah akad pinjaman (qardh) maka pinjaman tidak boleh dikembalikan berlebih dengan tambahan keuntungan yang diperjanjikan di awal akad.

\footnotetext{
${ }^{64}$ Abû Hâmid Muhammad bin Muhammad al Ghazâlî, al-Mustashfâ min 'Ilm al-Ushûl (Beirut: Dâr alFikr), 251.

${ }^{65}$ Hadi, Bunga Bank dalam Islam, 220.
} 
Bila dikembalikan berlebih dalam bentuk bunga maka bunga ini dinamakan riba.

2) Menabung di Bank Konvensional walaupun tidak mengambil bunganya tetaplah haram. Karena itu artinya kita telah membantu operasional dari pinjaman berbunga atau bisnis ribawi yang dijalankan bank tersebut. Dalam sebuah hadits, Dari Jabir ra., ia berkata:66

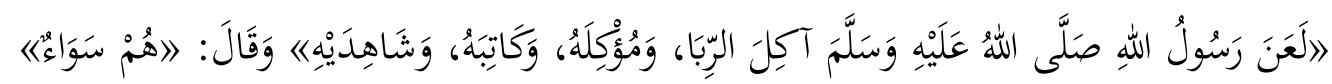

Rasulullah Shallallahu 'alaihi wa sallam mengutuk orang yang makan harta riba, yang memberikan riba, penulis transaksi riba dan dua orang saksi akad riba. Mereka semuanya sama". (HR. Muslim)

3) Jika seseorang sangat butuh membuka rekening di bank konvensional karena gajinya ditransfer oleh perusahaan ke rekening di bank konvensional maka hukumnya diberi keringanan dengan syarat, setelah uang masuk kerekening sesegera mungkin menariknya dan jika diberikan bunga oleh bank, bunga tersebut adalah riba yang wajib ia bebaskan dari hartanya dengan cara menyalurkannya untuk kepentingan sosial. Sebagaimana difatwakan oleh lembaga fatwa kerajaan Arab Saudi, No. 16051 ketika ditanya tentang hukum penerimaan gaji para pegawai melalui rekening di bak ribawi, yang berbunyi,"Gaji yang diterima melalui rekening di bank (riba) boleh agar anda dapat mendapatkan upah hasil kerja dengan syarat jangan ditingalkan di bank setelah masuk ke rekening agar tidak digunakan oleh bank untuk investasi riba.".67 Dengan begitu maka jelaslah sudah, bahwa bunga bank baik dalam produk simpanan maupun pinjaman adalah riba dan hukumnya haram.

\section{Fatwa-fatwa Terkait Bunga}

Kedudukan fatwa dalam hukum Islam dikenal sebagai salah satu referensi hukum yang dapat dipedomani. Pada awalnya fatwa diberikan secara perseorangan. Rasulullah saw. selalu memberikan jawaban terhadap

\footnotetext{
${ }^{66}$ Muslim bin al Hallaj Abû al Hasan al Qusyairi an Naisabûri, Shahîh Muslim, vol. 3 (Beirut: Dâr Ihyâ at-Turats), 129.

${ }^{67}$ Tarmizi, Harta Haram Muamalat Kontemporer, 355.
} 
Muhammad Syarif Hidayatullah

pertanyaan-pertanyaan yang diajukan sahabat. Jawaban-jawaban yang diberikan Rasul menjadi landasan hukum dan bersifat mengikat bagi kaum muslimin sebagai aturan syariah. Akan tetapi setelah beliau wafat, permasalahan tentang hukum ditanyakan kepada khalifah yang mengantikan beliau atau para ulama kurun itu. Apabila mereka tidak mendapatkan pedoman dari Al Qur'an dan Sunnah maka mereka berijtihad. Ijtihad yang diberikan sebagai sebuah keputusan perorangan disebut dengan fatwa. Fatwa sebagai legal opini seorang ulama pada waktu itu tidaklah mengikat berbeda dengan masa Rasulullah. Tetapi ia merupakan informasi hukum bagi orang yang membutuhkannya. Sehingga terkadang bahkan sering, fatwa antara satu ulama dengan ulama lainnya terhadap satu masalah yang sama bisa berbeda. Perkembangan berikutnya fatwa tidak lagi diberikan secara persendirian tapi bergeser kepada institusi atau lembaga resmi yang di buat oleh lembaga pemerintahan untuk mendapat pertimbangan-pertimbangan dalam hukum Islam. ${ }^{68}$

Hukum bahwa bunga bank sama dengan riba merupakan keputusan lembaga-lembaga atau komisi fatwa baik yang bertaraf nasional maupun internasional, antara lain:

1) Komisi Fatwa Majelis Ulama Indonesia

Fatwa MUI tentang keharaman bunga bank tercantum dalam Fatwa MUI No. 1 Tahun 2004 tentang bunga (interest/fa'idah) yang salah satu poinnya berbunyi:

a) Praktek pembungaan uang saat ini telah memenuhi kriteria riba yang terjadi pada zaman rasulullah saw. yakni riba nasi'ah. Dengan demikian praktek pembungaan uang ini termasuk salah satu bentuk riba, dan riba haram hukumnya.

b) Praktek pembungaan tersebut hukumnya adalah haram, baik dilakukan oleh bank, asuransi, pasar modal, pegadaian, koperasi, dan lembaga keuangan lainnya maupaun dilakukan oleh individu.

\footnotetext{
${ }^{68}$ Muhammad Yasir Yusuf, 'Dinamika Fatwa Bunga Bank di Indonesia: Kajian Terhadap Fatwa MUI, Muhammaddiyah dan Nahdhatul Ulama', Media Syari'ah, vol. 14, no. 2 (2012), 155-6.
} 
2) Lajnah Bahsul Masa'il Nahdhatul Ulama

Mengenai bank dan pembungaan uang, Lajnah memutuskan masalah tersebut melaui beberapa kali sidang. Menurut Lajnah, hukum bank dan hukum bunganya sama seperti hukum gadai. Terdapat tiga pendapat sehubungan dengan masalah ini, yakni: (a) Haram, sebab termasuk utang yang dipungut rente; (b) Halal, sebab tidak ada syarat pada waktu akad, sedangkan adat yang berlaku tidak dapat begitu saja dijadikan syarat; (c) Syubhat (tidak tentu halal-haramnya), sebab para ahli hukum berselisih pendapat tentangnya.

Meskipun ada perbedaan pandangan, Lajnah memutuskan bahwa (pilihan) yang lebih berhati-hati ialah pendapat pertama, yakni menyebut bunga bank adalah haram. ${ }^{69}$ Fatwa NU ini lebih menitik beratkan kepada kajian hukum yang telah diutarakan oleh ulama-ulama mazhab dan disampaikan dalalm kutub al mu'tabarah yaitu buku-buku terpandang yang dijadikan landasan dan pertimbangan dalam memberikan fatwa. Akan tetapi, dengan perkembangan Bank Syariah hingga sekarang, dengan keadaan yang sudah jauh berubah dengan masa dimana fatwa ini dikeluarkan, perkara yang penuh keragu-raguan (musytabihat atau syubhat) tentang bunga bankpun juga telah berubah. Saat ini Bank Syariah sudah bertebaran dimana-mana dan terdapat payung hukum yang kuat yaitu UU No. 21 Tahun 2008 tentang Perbankan Syariah. Dengan begitu kondisi darurat tidak adanya perbankan tanpa bunga menjadi tidak relevan lagi karena pertumbuhan perbankan syariah kian hari kian meningkat.

3) Majelis Tarjih Muhammadiyah

Fatwa yang pertama kali diputuskan oleh Muhammadiyah berkenaan dengan bunga bank adalah melalui Majelis Tarjih Sidoarjo (1968) yang

${ }^{69}$ Antonio, Bank Syariah, 63. 
salah satu bagian keputusannya:

“Bank dengan sistem riba hukumnya haram dan bank tanpa riba hukumnya halal; Bunga yang diberikan oleh bank-bank milik negara kepada para nasabahnya atau sebaliknya yang selama ini berlaku, termasuk perkara musytabihat."

Kemudian dalam perkembangannya, dikeluarkan lagi fatwa yang berhubungan dengan bunga bank secara lebih tegas dengan Fatwa Majelis Tarjih dan Tajdid PP Muhammadiyah No. 8 Tahun 2006 yang salah satu poinnya:

“Bunga adalah riba karena (1) merupakan tambahan atas pokok modal yang dipinjamkan, padahal Allah berfirman "...dan jika kamu bertaubat (dari pengambilan riba) maka bagimu pokok hartamu."(2) tambahan itu bersifat mengikat dan diperjanjikan sedangakn yang bersifat sukarela dan tidak diperjanjikan tidak termasuk riba."

4) Sidang Organisasi Kerjasama Islam (OKI) / Organisation of Islamic Cooperation (OIC)

Semua peserta sidang OKI kedua yang berlangsung di Karachi, Pakistan, Desember 1970, telah menyepakati dua hal utama, yaitu sebagai berikut: (a) Praktik bank dengan sistem bunga adalah tidak sesuai dengan syariah Islam; (b) Perlu segera didirikan bank-bank alternatif yang menjalankan operasinya sesuai dengan prinsip-prinsip syariah.

Hasil kesepakatan inilah yang melatarbelakangi didirikannya Bank Pembangunan Islam atau Islamic Development Bank (IDB)..$^{70}$

5) Mufti Negara Mesir

Keputusan Kantor Mufti Negara Mesir terhadap hukum bunga bank senantiasa tetap dan konsisten. Tercatat sekurang-kurangnya sejak tahun 1900 hingga 1989, Mufti Republik Arab Mesir memutuskan bahwa bunga bank termasuk salah satu bentuk riba yang diharamkan. ${ }^{71}$

6) Konsul Kajian Islam Dunia

Ulama-ulama besar dunia yang terheimpun dalam Konsul Kajian Islam

70 Ibid., 65.

${ }^{71}$ Ibid., 65-6. 
Dunia (KKID) telah memutuskan hukum yang tegas terhadap bunga bank. Dalam konferensi II KKID yang diselenggarakan di Universitas al-Azhar, Kairo, pada bulan Muharram 1385 H/Mei 1965 M, ditetapkan bahwa tidak ada sedikit pun keraguan atas keharaman praktik pembungaan uang seperti yang dilakukan bank-bank konvensional. Diantara ulama-ulama besar yang hadir pada saat itu adalah Syekh al-Azhar Prof. Abû Zahrah, Prof. Abdullah Draz, Prof. Dr. Musthafâ Ahmad az Zarqâ, Dr. Yûsuf alQaradhâwî dan sekitar tiga ratus ulama besar dunia lainnya. Konferensi ini disamping dihadiri oleh para ulama juga diikuti oleh para bankir dan ekonom dari Amerika, Eropa, dan dunia Islam. Yang menarik, para bankir dan ekonom justru yang paling semangat menganalisis kemudharatan praktik pembungaan uang melebihi hammasah (semangat) para ustadz dan ahli syariah. mereka menyerukan bahwa harus dicari satu bentuk sistem perbankan alternatif. ${ }^{2}$

7) Fawa Lembaga-lembaga lain

Senada dengan ketetapan dan fatwa dari lembaga-lembaga Islam dunia di atas, beberapa lembaga berikut ini juga menyatakan bahwa bunga bank adalah salah satu bentuk riba yang diharamkan. Lembaga-lembaga tersebut yakni Akademi Fiqih Liga Muslim Dunia dan Pimpinan Pusat Dakwah, Penyuluhan, Kajian Islam, dan Fatwa, Kerajaan Saudi Arabia. ${ }^{73}$

Selain apa yang disebutkan di atas, keputusan pengharaman bunga bank juga terdapat dalam Majmấ' Fiqh Rabithah al-'Alam al Islâmî Keputusan 6 Sidang IX yang diselenggarakan di Makkah tanggal 12 - 19 Rajab 1406 H, Keputusan Supreme Shariah Court Pakistan 22 Desember 1999, Keputusan Muktamar kedua tentang ekonomi Islam di Kuwait pada tahun 1403 H/1983 M dan Keputusan Majma' Fiqih Islam di India pada bulan Jumadil awal 1410 $\mathrm{H}$.

\footnotetext{
${ }^{72}$ Ibid., 66.

${ }^{73} \mathrm{Ibid}$.
} 


\section{Sistem Bagi Hasil VS Bunga}

Salah satu pembeda antara Bank Syariah dan Bank Konvensional adalah pada sistem yang dijalankan. Bank Syariah melakukan operasi berdasarkan prinsip syariah dan salah satunya adalah melalui pendapatan yang didapatkan dengan sistem bagi hasil, berbedahalnya dengan Bank Konvensional yang pendapatannya berasal dari sistem bunga.

\section{Tabel 5}

Perbedaan Bagi Hasil dengan Bunga

\begin{tabular}{|l|l|}
\hline \multicolumn{1}{|c|}{ Bagi Hasil } & \multicolumn{1}{|c|}{ Bunga } \\
\hline Akad kerja sama (syirkah) & $\begin{array}{l}\text { Akad utang-piutang/pinjaman uang } \\
\text { (qardh) }\end{array}$ \\
\hline $\begin{array}{l}\text { Penentuan besarnya rasio/nisbah } \\
\text { bagi hasil dibuat pada waktu akad } \\
\text { dengan berpedoman pada } \\
\text { kemungkinan untung atau rugi. }\end{array}$ & $\begin{array}{l}\text { Penentuan bunga dibuat pada } \\
\text { waktu aqad dengan asumsi harus } \\
\text { selalu untung. }\end{array}$ \\
\hline $\begin{array}{l}\text { Penentuan besarnya hasil diketahui } \\
\text { setelah proyek usaha dijalankan }\end{array}$ & $\begin{array}{l}\text { Penentuan besarnya hasil diawal } \\
\text { sebelum proyek usaha dijalankan }\end{array}$ \\
\hline $\begin{array}{l}\text { Dihitung berdasarkan nisbah bagi } \\
\text { hasil yang diambil dari keuntungan } \\
\text { nyata usaha yang dijalankan }\end{array}$ & \begin{tabular}{l} 
Dihitung dari pokok utang \\
\hline Bersifat Fluktuatif.
\end{tabular} \\
\hline $\begin{array}{l}\text { Nominal berubah sesuai kondisi } \\
\text { usaha (Jumlah pembagian laba } \\
\text { meningkat sesuai dengan } \\
\text { peningkatan jumlah pendapatan) }\end{array}$ & $\begin{array}{l}\text { Nominal tetap sesuai bunga (Jumlah } \\
\text { pembayaran bunga tidak meningkat } \\
\text { sekalipun jumlah keuntungan } \\
\text { berlipat atau keadaan ekonomi } \\
\text { sedang booming) }\end{array}$ \\
\hline $\begin{array}{l}\text { Pendekatan sektor riil } \\
\text { Sah }\end{array}$ & \begin{tabular}{l} 
Pendekatan sektor moneter \\
\hline Halal
\end{tabular} \\
\hline
\end{tabular}

\section{Penutup}

Pada dasarnya akad yang diterapkan bank konvensional dalam operasionalnya dengan praktik pembungaan uang adalah akad qardh (utangpiutang/pinjaman uang. Penarikan keuntungan dilakukan pada akad yang keberadaanya sebagai akad tabarru' atau tathawwu'i yang sifatnya adalah 
sosial dan murni tolong-menolong. Inilah kesalahan mendasar bank konvensional yang bertentangan dengan prinsip syariah, yakni menjadikan akad yang seharusnya bersifat sosial/nirlaba dan tolong menolong sebagai akad komersial bahkan sebagai jantung usaha. Dalam hal ini bank konvensional telah mengkomersialisasikan akad qardh, sedangkan dalam hukum Islam keberadaanya bukanlah sebagai akad bisnis (tijarah). Bunga bank merupakan perwujudan riba kontemporer dalam perekonomian modern yang dalam perspektif hukum Islam adalah transaksi ribawi yang hukumnya haram, baik dalam nominal rendah maupun berganda, dalam jumlah banyak maupun sedikit, serta dalam pinjaman konsumtif maupun produktif. Bunga pula menjadi representasi prinsip time value of money (sistem ekonomi kapitalis) yang menjadikan uang sebagai komoditas.

Islam tidaklah melarang untuk mencari keuntungan dalam bisnis, namun ada aturannya, yakni gunakanlah akad yang memang sesuai syariat adalah akad komersial seperti syirkah, bai' dan ijarah dan menghindari segala unsur terlarang dalam muamalah. Sedangkan penggunaan akad qardh sebagai jantung usaha bisnis telah melanggar prinsip syariah sebab bunga yang menjadi keuntungan didalamnya adalah sama dengan riba dan hukumnya haram. Praktik pembungaan inipun menyalahi kaidah al-al-ghurmu bi alghunmi dan al-kharaj bi adh-dhamân, dimana untung muncul bersama resiko dan hasil usaha muncul bersama biaya. Ketetapan akan keharaman bunga bank juga telah banyak dikeluarkan oleh berbagai lembaga/komisi/forum ulama baik yang bertaraf nasional maupun internasional.

\section{DAFTAR PUSTAKA}

Abdullah, M. Ma'ruf, Hukum Perbankan dan Perkembangan Bank Syariah Di Indonesia, Banjarmasin: Antasari Press, 2006. 
Muhammad Syarif Hidayatullah

al Andalusî, Abû al Walîd Muhammad bin Ahmad bin Muhammad bin Rusyd, Bidâyah al-Mujtahid wa an-Nihâyah al-Muqtashid, vol. 2, Beirut: Dâr al-Ma'rifah.

Antonio, Muhammad Syafi'i, Bank Syariah: dari teori ke praktik, Jakarta: Gema Insani, 2009.

al 'Asqalânî, Abu al Fadhl Ahmad bin 'Alî bin Hajar, Bulûgh al-Marâm min Adillat al-Ahkâm, Riyadh: Dâr al-Falaq, 1424.

Azhari, Fathurrahman, Qawaid Fighiyyah Muamalah, Banjarmasin: Lembaga Pengembangan Kualitas Umat, 2014.

----, Ushul Fiqh Ekonomi dan Keuangan Syariah, Depok: RajaGrafindo Persada, 2019.

Badri, Muhammad Arifin, Riba dan Tinjauan Kritis Perbankan Syariah, Bogor: Darul Ilmi, 2012.

al Baihaqî, Abû Bakar Ahmad bin al Husain bin 'Alî bin 'Abdullah bin Mûsa al Khusraujirdî, as-Sunan al-Kubrâ, vol. 5, Beirut: Dâr al-Kutub al-‘Ilmiyah, 2003.

al-Bassâm, Abû 'Abdurrahmân 'Abdullah bin 'Abdurrahmân bin Shâlih bin Hammad bin Muhammad bin Hammad, Taisîr al-'Allâm Syarah 'Umdah al-Ahkâm, Beirut: Maktabah at-Tâbi'în, 2006.

Cipta, Hendra, 'Jual Beli yang Diridhoi dalam Perspektif Surat An-Nisa' (4) Ayat 29', ASY SYAR'TYYAH: JURNAL ILMU SYARI'AH DAN PERBANKAN ISLAM, vol. 3, no. 2, 2018, pp. 47-62

ad Dâraynî, Fathi, al-Minhâj al-Ushûliyyah fî̀ Ijtihâd bî̀ ar-Ra'yi fî at-Tasyrî', Damaskus: Dâr al-Kutub al-Hadîts, 1975.

Djamil, Fathurrahman, Filsafat Hukum Islam, Jakarta: Logos Wacana Ilmu, 1997.

Fahmi, Annas Syams Rizal et al., 'Implementasi Fatwa Dsn-Mui No: 77/DsnMui/V/2010 Terhadap Akad Murabahah Pada Produk Cicil Emas Di 
Bank Syariah Mandiri', Al-Mizan: Jurnal Hukum dan Ekonomi Islam, vol. 4, no. 2, 2020, pp. 1-12 [https://doi.org/10.33511/almizan.v4n2.1-12].

Fila, Siti Zafilah Firdausiah, 'Kajian Teoritik Terhadap Urgensi Asas Dalam Akad (Kontrak) Syariah', Al - Muamalat: Jurnal Hukum dan Ekonomi Syariah, vol. 5, no. 1, 2020, pp. 48-67 [https://doi.org/10.32505/muamalat.v5i1.1519].

Fitriani, Fitriani and Indra Marzuki, 'Analisis penerapan aspek syariah pada digitalisasi Bisnis pariwisata halal':, Al-Mizan: Jurnal Hukum dan Ekonomi Islam, vol. 4, no. 2, 2020, pp. 80-95

al Ghazâlî, Abû Hâmid Muhammad bin Muhammad, al-Mustashfâ min 'Ilm alUshûl, Beirut: Dâr al-Fikr.

Hadi, Abu Sura'i Abdul, Bunga Bank dalam Islam, trans. by M. Thalib, Surabaya: al-Ikhlas, 1993.

Hasbiyallah, Sudah Syar'ikah Muamalahmu?: Panduan Memahami Seluk-beluk Figh Muamalah, Yogyakarta: Salma Idea, 2014.

Hasyim, Muhammad Syarif, 'Bunga Bank: Antara Paradigma Tekstual Dan Kontekstual', HUNAFA: Jurnal Studia Islamika, vol. 5, no. 1, 2008, pp. 4558 [https://doi.org/10.24239/jsi.v5i1.151.45-58].

Hisan, Moh Syifa 'ul, 'Riba dan Bunga dalam Kontrak Syariah', SYARIATI, vol. 5, nos. 02, Nov, 2019, pp. 255-70.

Ilyas, Rahmat, 'Konsep Dasar Dalam Sistem Keuangan Syariah', ASY SYAR'IYYAH: JURNAL ILMU SYARI'AH DAN PERBANKAN ISLAM, vol. 2, no. 1, 2017, pp. 121-42 [https://doi.org/10.32923/asy.v2i1.594].

Ismâ'îl, Muhammad Muhammad, al-Fikr al-Islâm, Beirut: al-Maktabah al-Wa'î, 1958.

Karim, Adiwarman A., Ekonomi Islam: Suatu Kajian Kontemporer, Jakarta: Gema Insani, 2001.

----, Bank Islam: Analisis Fiqih dan Keuangan, Jakarta: RajaGrafindo Persada, 2008. 
Muhammad Syarif Hidayatullah

Kasim, Dulsukmi Kasim, 'Kondisi Sosio-Historis Dibalik Teks Pengharaman Riba Dan Implikasinya Terhadap Pegawai Bank KonvensionaL', Hukum Islam, vol. 20, no. 1, 2020, pp. 1-25

Khallâf, 'Abdul Wahhâb, 'Ilm Ushûl al-Fiqh, Kairo: Maktabah ad-Da'wah alIslâmiyyah Syabâb al-Azhar.

al Maqdisî, Muwaffaquddîn Abû Muhammad 'Abdullah bin Ahmad bin Muhammad bin Qudâmah, al-Mughnî, vol. 4, Kairo: Maktabah alQâhirah, 1968.

Marheni, Marheni, 'Analisis Kepatuhan Prinsip-Prinsip Syariah Terhadap Kesehatan Finansial Dan Fraud pada Bank Umum Syariah', ASY SYAR'IYYAH: JURNAL ILMU SYARI'AH DAN PERBANKAN ISLAM, vol. 2, no. 1, 2017, pp. 143-70 [https:// doi.org/10.32923/asy.v2i1.596].

al Mishrî, Rafîq Yûnus, al-Jâmi' fî̀ Ushûl ar-Ribâa, Damaskus: Dâr al-Qalam, 2001.

----, Ribâ al-Qurûdh wa Adillah Tahrîmih, Damaskus: Dâr al-Maktabî, 2009.

Mubarok, Jaih, 'Riba dalam Transaksi Keuangan', At-Taradhi Jurnal Studi Ekonomi, vol. 6, no. 1, 2015.

Mufid, Mohammad, Ushul Figh Ekonomi dan Keuangan Kontemporer: Dari Teori Ke Aplikasi, Jakarta: Kencana, 2016.

Muhammad, Lembaga-lembaga Keuangan Umat Kontemporer, Yogyakarta: UII Press, 2000.

Mutasowifin, Ali, 'Menggagas Strategi Pengembangan Perbankan Syariah di Pasar Nonmuslim', Jurnal Universitas Paramadina, vol. 3, no. 1, 2003, pp. 25-39.

an Naisabûri, Muslim bin al Hallaj Abû al Hasan al Qusyairi, Shahîh Muslim, vol. 3, Beirut: Dâr Ihyâ at-Turats.

Nawawi, Ismail, Fikih Muamalah Klasik dan Kontemporer, Bogor: Ghalia Indonesia, 2012. 
Pakpahan, Elpianti Sahara, 'Pengharaman Riba Dalam Islam', AL-HADI, vol. 4, no. 2, 2020, pp. 865-76.

al Qaradhâwî, Yûsuf, Fawâ'id al-Bunûk hiya al-Ribâ al-Harâm, Kairo: Dâr alShahwah, 1994.

----, Fatwa-fatwa Mutakhir, trans. by H.M.H. al-Hamid al-Husaini, Jakarta: Yayasan al-Hamidiy, 1995.

ar Râzî, Fakhruddîn Muhammad bin 'Umar bin al-Husain, al-Ma'âlim fì 'Ilm Ushûl al-Fiqh, Kairo: Dâr al-Ma'rifah, 1994.

ash Sadr, Muhammad Baqir, Buku Induk Ekonomi Islam: Iqtishaduna, trans. by Yudi, Jakarta: Zahra, 2008.

as Salâm, al Izz bin 'Abd, Qawấ'id al-Ahkâm fî Mashâlih al-Anâm, Beirut: Dâr alKutub al-'Ilmiyah, 2001.

Soemitra, Andri, Bank dan Lembaga Keuangan Syariah, Jakarta: Kencana, 2009.

Sumar'in, Sumar'in, 'Optimalisasi Peran Dewan Pengawas Syariah (DPS)

Dalam Menjaga Kepatuhan Syariah Pada Perbankan Syariah di Indonesia', ASY SYAR'IYYAH: JURNAL ILMU SYARI'AH DAN PERBANKAN ISLAM, vol. 2, no. 1, 2017, pp. 196-220 [https://doi.org/10.32923/asy.v2i1.598].

Syafe'i, Rachmat, Figh Muamalah, Bandung: Pustaka Setia, 2001.

asy Syâthibî, Abû Ishâq Ibrâhîm bin Mûsâ bin Muhammad al-Khamrî alGharnâthî, al-Muwâfaqât fî Ushîl asy-Syarî'ah, vol. 1, Kairo: Mustafa Muhammad.

Tarmizi, Erwandi, Harta Haram Muamalat Kontemporer, Bogor: Berkat Mulia Insani, 2013.

Usâmah, Abû Muhammad al Hârits bin Muhammad bin Dâhir at Tamîmî al Baghdâdî al Khushaib al Ma'rûf bin Abî, Bughyah al-Bâhits 'an Zawâid Musnad al-Hârits, vol. 1, Madinah Munawwarah: Markaz Khidmah asSunnah wa as-Sîrah an-Nabawiyah, 1992. 
Muhammad Syarif Hidayatullah

Wulpiah, Wulpiah, 'Urgensi Penerapan Kepatuhan Syariah pada Perbankan Syariah (Telaah Konseptual-Analitis)', ASY SYAR'TYYAH: JURNAL ILMU SYARI'AH DAN PERBANKAN ISLAM, vol. 2, no. 1, 2017, pp. 100-20

Yusuf, Muhammad Yasir, ‘Dinamika Fatwa Bunga Bank di Indonesia: Kajian Terhadap Fatwa MUI, Muhammaddiyah dan Nahdhatul Ulama', Media Syari'ah, vol. 14, no. 2, 2012, pp. 151-60.

Zaelani, Abdul Qodir, ‘Bunga Bank dalam Perspektif Sosio-Ekonomi dan Ushul Fiqh (Studi Atas Pemikiran M. Umer Chapra)', ASAS, vol. 4, no. $2,2012$.

Zahrah, Muhammad Abû, Buhûts fî ar-Ribâ, Kairo: Dâr al-Fikr al' Arabî.

az Zuhailî, Wahbah, al-Figh al-Islâmî wa Adillatuh, vol. 5, Damaskus: Dar alFikr. 